\title{
Preparation and Performance of Cerium-Based Catalysts for Selective Catalytic Reduction of Nitrogen Oxides: A Critical Review
}

\author{
Ming Cai, Xue Bian *, Feng Xie *, Wenyuan Wu and Peng Cen (D) \\ School of Metallurgy, Northeastern University, NO.3-11 Wenhua Road, Shenyang 110819, China; \\ 1910573@stu.neu.edu.cn (M.C.); wuwy@smm.neu.edu.cn (W.W.); cenpeng@smm.neu.edu.cn (P.C.) \\ * Correspondence: bianx@smm.neu.edu.cn (X.B.); xief@smm.neu.edu.cn (F.X.)
}

Citation: Cai, M.; Bian, X.; Xie, F.; $\mathrm{Wu}, \mathrm{W}$; Cen, P. Preparation and Performance of Cerium-Based Catalysts for Selective Catalytic Reduction of Nitrogen Oxides: A Critical Review. Catalysts 2021, 11, 361. https://doi.org/10.3390/ catal11030361

Academic Editor: Anker Degn Jensen

Received: 17 February 2021

Accepted: 7 March 2021

Published: 10 March 2021

Publisher's Note: MDPI stays neutral with regard to jurisdictional claims in published maps and institutional affiliations.

Copyright: (c) 2021 by the authors. Licensee MDPI, Basel, Switzerland. This article is an open access article distributed under the terms and conditions of the Creative Commons Attribution (CC BY) license (https:// creativecommons.org/licenses/by/ $4.0 /)$.

\begin{abstract}
Selective catalytic reduction of nitrogen oxides with $\mathrm{NH}_{3}\left(\mathrm{NH}_{3}-\mathrm{SCR}\right)$ is still the most commonly used control technology for nitrogen oxides emission. Specifically, the application of rare earth materials has become more and more extensive. $\mathrm{CeO}_{2}$ was widely developed in $\mathrm{NH}_{3}$-SCR reaction due to its good redox performance, proper surface acidity and abundant resource reserves. Therefore, a large number of papers in the literature have described the research of cerium-based catalysts. This review critically summarized the development of the different components of ceriumbased catalysts, and characterized the preparation methods, the catalytic performance and reaction mechanisms of the cerium-based catalysts for $\mathrm{NH}_{3}-\mathrm{SCR}$. The purpose of this review is to highlight: (1) the modification effect of the various metal elements for cerium-based catalysts; (2) various synthesis methods of the cerium-based catalysts; and (3) the physicochemical properties of the various catalysts and clarify their relations to catalytic performances, particularly in the presence of $\mathrm{SO}_{2}$ and $\mathrm{H}_{2} \mathrm{O}$. Finally, we hope that this work can give timely technical guidance and valuable insights for the applications of $\mathrm{NH}_{3}-\mathrm{SCR}$ in the field of $\mathrm{NO}_{x}$ control.
\end{abstract}

Keywords: selective catalytic reduction; cerium-based catalysts; denitration; physicochemical properties; catalytic performance

\section{Introduction}

$\mathrm{NO}_{\mathrm{x}}$ emissions from automobile exhausts and stationary sources pose a serious threat to environment. In 2017, the national $\mathrm{NO}_{\mathrm{x}}$ emission reached 17,852,200 tons, of which the $\mathrm{NO}_{\mathrm{x}}$ emissions from industrial sources was 6,459,000 tons, accounting for $36.2 \%$ of the total $\mathrm{NO}_{\mathrm{x}}$ emissions, and the $\mathrm{NO}_{\mathrm{x}}$ emissions from thermal power plants ranked first among the total $\mathrm{NO}_{\mathrm{x}}$ emissions from the key industrial enterprises under investigation [1]. Meanwhile, many countries have issued a number of laws and measures to strictly control $\mathrm{NO}_{\mathrm{x}}$ emissions, such as the New Sources Performance Standard of the United States, the Large Combustion Plant Directive: H 2001/80/EC of the European Union, the Air Pollution Prevention Law of Japan, the Atmospheric Environment Preservation Law of South Korea and the Thermal Power Plant of China (GB13223-2011).

The most promising approach to reduce $\mathrm{NO}_{x}$ emissions is the selective catalytic reduction of $\mathrm{NO}_{x}$ with $\mathrm{NH}_{3}$. The $\mathrm{V}_{2} \mathrm{O}_{5}-\mathrm{WO}_{3} / \mathrm{TiO}_{2}$ and $\mathrm{V}_{2} \mathrm{O}_{5}-\mathrm{MoO}_{3} / \mathrm{TiO}_{2}$ commercial catalysts were conventionally developed for $\mathrm{NH}_{3}-\mathrm{SCR}$, because of their excellent catalytic performance and strong stability [2-5]. However, the poor catalytic temperature window $\left(300 \sim 400{ }^{\circ} \mathrm{C}\right.$ ) and the toxicity of vanadium also bring difficulties for the disposal of the waste catalysts, which limit the future development of the vanadium-based catalysts $[6,7]$. Therefore, non-vanadium-based $\mathrm{NH}_{3}$-SCR catalysts currently attract significantly more attention in this field.

Apparently, China is the country with the most abundant rare earth mineral resources in the world, with not only with large reserves, but more importantly with complete mineral species and relatively low costs $[8,9]$. If rare earth oxide is applied to the research and 
development of SCR catalysts, it can develop the high efficiency deNO $\mathrm{N}_{\mathrm{x}}$ from industrial sources and automobile exhausts at low costs, which is the technical route for the preparation of SCR catalysts in accordance with China's national conditions. Especially, $\mathrm{CeO}_{2}$ plays a key role in the treatment of automobile exhausts, and also has certain significance for the abatement of particulate matter $[10,11]$.

$\mathrm{Up}$ to now, $\mathrm{CeO}_{2}$ as the main active component and promoter of $\mathrm{NH}_{3}-\mathrm{SCR}$ catalysts has been widely studied [12-14]. In general, $\mathrm{CeO}_{2}$ is an acid-based substance, which has a large number of Lewis acid sites and a few Brönsted acid sites. $\mathrm{CeO}_{2}$ is as an oxygen reservoir, which stores and releases oxygen via the redox shift between $\mathrm{Ce}^{4+}$ and $\mathrm{Ce}^{3+}$ under oxidizing and reducing conditions. Besides, $\mathrm{CeO}_{2}$ exhibited an excellent SCR activity in the presence of $\mathrm{SO}_{2}$ at $300-500{ }^{\circ} \mathrm{C}$ [15-18]. Furthermore, the most important properties of suitable surface acidity and good redox ability play a significant role in SCR performance $[19,20]$. Therefore, cerium-based catalysts were widely studied in $\mathrm{NH}_{3}-\mathrm{SCR}$ reaction $[21,22]$. In this paper, the research progress of cerium-based $\mathrm{NH}_{3}-\mathrm{SCR}$ catalysts made in recent years is summarized, including cerium-based bimetallic oxide catalysts, cerium-based multiplex oxide catalysts and cerium-based molecular sieve catalysts.

\section{Cerium-Based Bimetallic Oxide Catalysts}

$\mathrm{CeO}_{2}$ enhances redox performance of the catalysts, which is vital for the catalytic reaction. Obviously, $\mathrm{CeO}_{2}$ is responsible for the oxygen storage through the redox reaction, and $\mathrm{Ce}^{3+}$ increases the amount of unstable surface oxygen holes and oxygen free radicals [23-26]. However, the $\mathrm{SCR}$ performance of pure $\mathrm{CeO}_{2}$ catalyst is poor, so many researchers have focused on synthesizing different composite catalysts for promoting $\mathrm{NH}_{3}$-SCR activity and extending the operating temperature windows. Therefore, the performance of cerium-based catalysts is continuously optimized by adding different metal oxides $[27,28]$.

\section{1. $\mathrm{CeO}_{2}-\mathrm{TiO}_{2}$ Catalyst}

Firstly, the $\mathrm{CeO}_{2}-\mathrm{TiO}_{2}$ catalyst has been widely concerned due to good redox performance and its high specific surface area on the surface of catalyst $[29,30]$. As is known to all, $\mathrm{TiO}_{2}$ is an optimal support of $\mathrm{NH}_{3}-\mathrm{SCR}$ catalysts with strong Lewis acidity and good $\mathrm{SO}_{2}$ durability. Meanwhile, active components can be uniformly dispersed on its surface, consequently increasing the number of surface active sites [31,32]. Generally, the preparation methods of the $\mathrm{CeO}_{2}-\mathrm{TiO}_{2}$ catalyst directly affect the strong interaction between $\mathrm{CeO}_{2}$ and $\mathrm{TiO}_{2}$ and the dispersion state of $\mathrm{CeO}_{2}$ on the catalyst's surface. The former mainly increases the specific surface. The latter directly affects the content of $\mathrm{Ce}^{3+}$ on the surface, thereby determining the redox performance of the catalysts. For example, Gao et al. [33,34] systematically compared the $\mathrm{CeO}_{2}-\mathrm{TiO}_{2}$ catalysts obtained by impregnation method, solgel method and coprecipitation method. The results found that the catalyst prepared by the sol-gel method showed up to $93-98 \% \mathrm{NO}_{x}$ conversion at $300-400{ }^{\circ} \mathrm{C}$. More specifically, the good deNO $\mathrm{N}_{x}$ performance might be attributed to the strong interaction between $\mathrm{CeO}_{2}$ and $\mathrm{TiO}_{2}$, shown in Figure 1. In addition, it can be also observed from Figure 2 that the primary particle size of CeTi (sol-gel) was less than $10 \mathrm{~nm}$; meanwhile, these pictures revealed that $\mathrm{CeO}_{2}$ was well dispersed on the surface of $\mathrm{TiO}_{2}$, thereby improving the catalytic activity of the catalysts. Similarly, Duan et al. [35] found that $\mathrm{CeO}_{2}$ can be uniformly dispersed on the $\mathrm{TiO}_{2} ;$ moreover, the levels of $\mathrm{CeO}_{2}$ in the catalyst did not change the crystal structure of the anatase. Obviously, the preparation methods of the sol-gel have great impact on the strong molecular interaction and surface characteristics of catalysts, which determine the $\mathrm{NH}_{3}$-SCR performance. Besides, Huang et al. [36] obtained a series of $\mathrm{CeO}_{2} / \mathrm{TiO}_{2}$ catalysts with organic additives by the ball milling method. The results indicated that the addition of citric acid into the ball milling process could significantly change the proceedings of the precursor mixture decomposition, enhancing the dispersion and reducibility of the $\mathrm{CeO}_{2}$ and the surface acidity as well as the surface microstructure. 


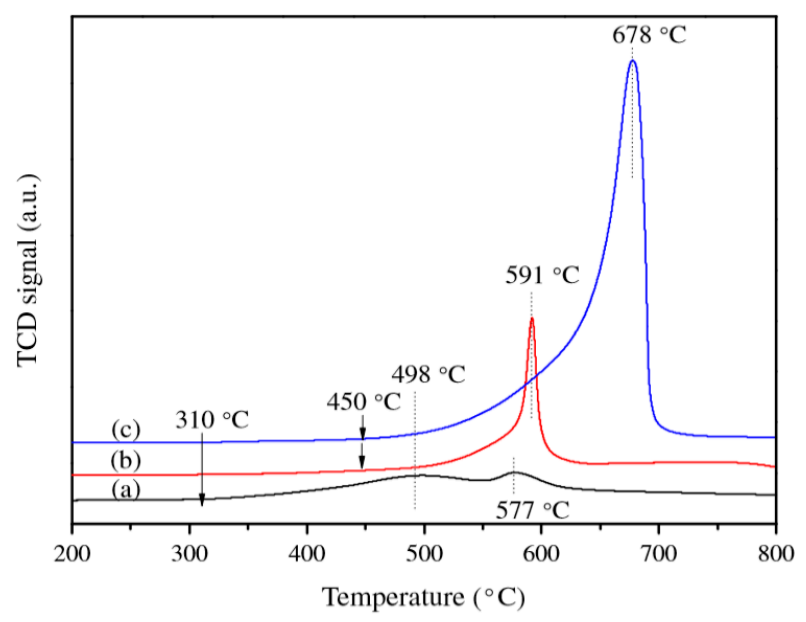

Figure 1. $\mathrm{H}_{2}$-TPR profiles of the catalysts: (a) CeTi (sol-gel method), (b) CeTi (impregnation method), (c) CeTi (coprecipitation method) [33,34].
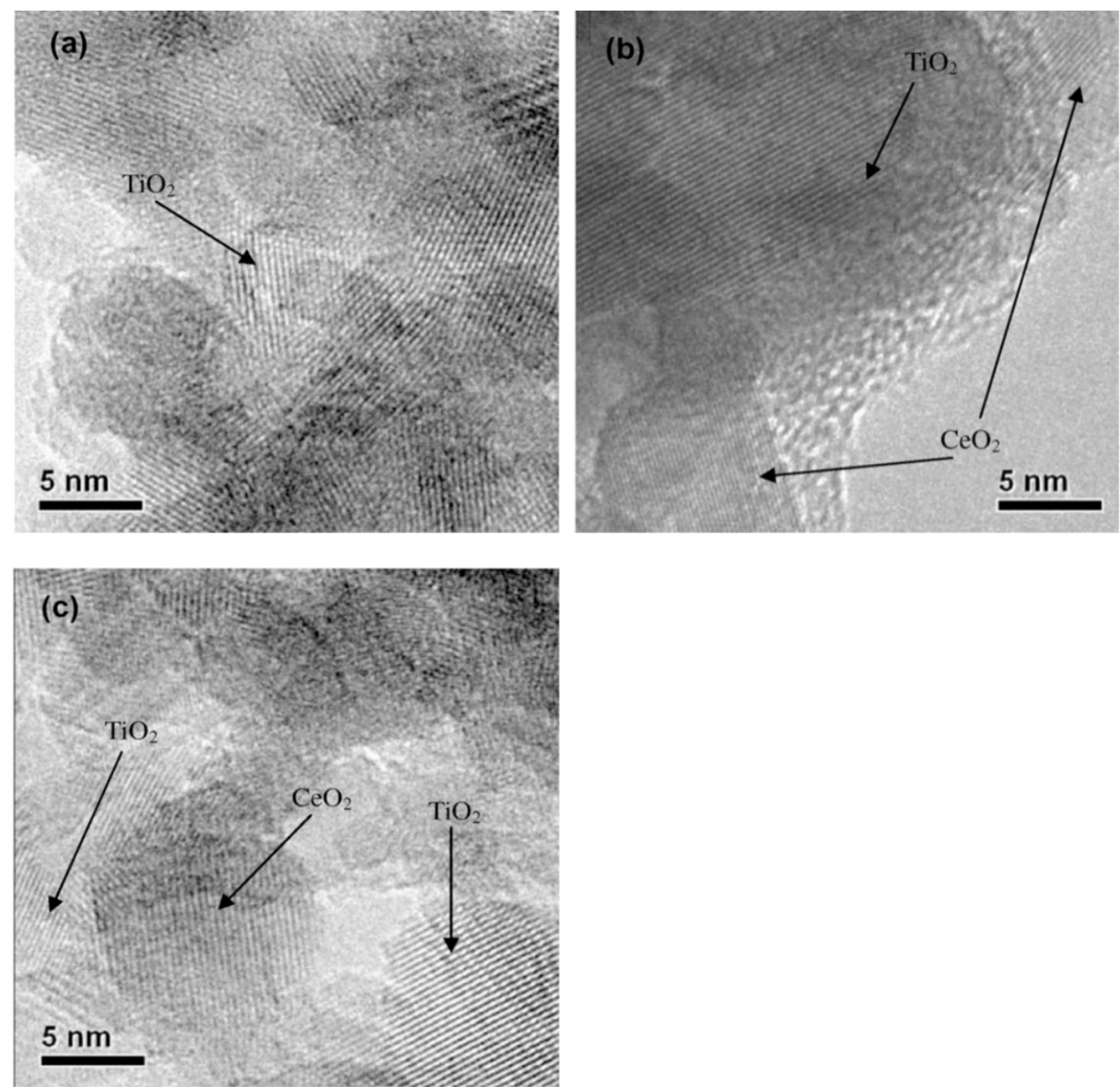

Figure 2. HR-TEM micrographs of the catalysts: (a) CeTi (sol-gel method), (b) CeTi (impregnation method) and (c) CeTi (coprecipitation method) $[33,34]$.

Furthermore, the presence of $\mathrm{CeO}_{2}$ in the $\mathrm{CeO}_{2}-\mathrm{TiO}_{2}$ catalyst can effectively enhance the catalytic activity and thermostability of $\mathrm{TiO}_{2}$. Especially, ceria atoms can inhibit the 
crystalline grain growth and the collapse of the small channels generated by calcination [37]. In addition, some studies have found that the sulfate formed in the presence of $\mathrm{SO}_{2}$ is unstable on the surface of $\mathrm{TiO}_{2}$ and is easily decomposed; thus, $\mathrm{TiO}_{2}$ has high $\mathrm{SO}_{2}$ durability performance [38]. The function of the $\mathrm{CeO}_{2}-\mathrm{TiO}_{2}$ catalyst has been evaluated by Fei et al. [39]. Particularly, the $\mathrm{Ce}_{0.5} \mathrm{Ti}_{0.5}$ catalyst exhibited the best catalytic activity and extraordinary $\mathrm{H}_{2} \mathrm{O} / \mathrm{SO}_{2}$ durability (Figures 3 and 4). Furthermore, the mechanism of $\mathrm{NH}_{3}$-SCR over $\mathrm{Ce}_{\mathrm{a}} \mathrm{Ti}_{1-\mathrm{a}}$ catalysts was confirmed in Figure 5, where $\mathrm{NH}_{3}$, as the main active intermediate, reacted with $\mathrm{NO}$ to produce $\mathrm{N}_{2}$ and $\mathrm{H}_{2} \mathrm{O}$ in the E-R mechanism (Pathway 1). Besides, for the L-H mechanism, a large amount of $\mathrm{Ce}^{3+}$ species and high surface adsorbed oxygen reacted with adsorbed $\mathrm{NH}_{3}$ through the "fast SCR", (Pathway 2). Subsequently, $\mathrm{NO}$ firstly adsorbed on the active sites and reacted with $\mathrm{O}^{-}$to form the intermediate, and lastly reacted with the adsorbed $\mathrm{NH}_{3}$ to form $\mathrm{N}_{2}$ and $\mathrm{H}_{2} \mathrm{O}$ (Pathway 3). Meanwhile, the effect of the loading sequence of $\mathrm{CeO}_{2}$ and $\mathrm{TiO}_{2}$ on the catalytic activity was investigated by Zhang et al. [40]. They also found that the $\mathrm{TiO}_{2} / \mathrm{CeO}_{2}$ catalyst not only showed good low-temperature activity at $150 \sim 250{ }^{\circ} \mathrm{C}$, but also showed great $\mathrm{SO}_{2}$ resistance performance with the existence of $200 \mathrm{ppm} \mathrm{SO}$ at $300{ }^{\circ} \mathrm{C}$. Actually, a large amount of $\mathrm{CeO}_{2}$ will actively react with $\mathrm{SO}_{2}$ in priority, avoiding the interaction between the $\mathrm{SO}_{2}$ and $\mathrm{Ce}-\mathrm{O}-\mathrm{Ti}$ active species; thereby the active species can completely exhibit great deNO $\mathrm{N}_{\mathrm{x}}$ performance, as shown in Figure 6. Additionally, some investigators have done some work on the influence of different precursors of $\mathrm{CeO}_{2}$ and $\mathrm{TiO}_{2}$ on the catalysts' performance. For instance, Yao et al. [41] synthesized $\mathrm{CeO}_{2} / \mathrm{TiO}_{2}$ catalyst with anatase, brookite and rutile $\mathrm{TiO}_{2}$ as support. The catalyst with rutile $\mathrm{TiO}_{2}$ exhibited great $\mathrm{NH}_{3}-\mathrm{SCR}$ activity owing to the large amount of acid sites, surface $\mathrm{Ce}^{3+}$ content, and surface adsorbed oxygen species. However, the $\mathrm{H}_{2} \mathrm{O} / \mathrm{SO}_{2}$ durability performances of $\mathrm{CeO}_{2} / \mathrm{TiO}_{2}$ catalyst with rutile $\mathrm{TiO}_{2}$ need to be further studied and improved. The abovementioned reports suggested that $\mathrm{CeO}_{2}$ and $\mathrm{TiO}_{2}$ exhibited more acid sites and higher dispersion than the pure $\mathrm{CeO}_{2}$, which significantly enhanced the catalytic activity of the catalysts. $\mathrm{SO}_{2}$ and $\mathrm{H}_{2} \mathrm{O}$ showed a promotion on $\mathrm{NO}_{\mathrm{x}}$ reduction over $\mathrm{Ce} / \mathrm{TiO}_{2}$ catalyst at higher temperature, whereas they show a great inhibitory effect at low temperature [42].

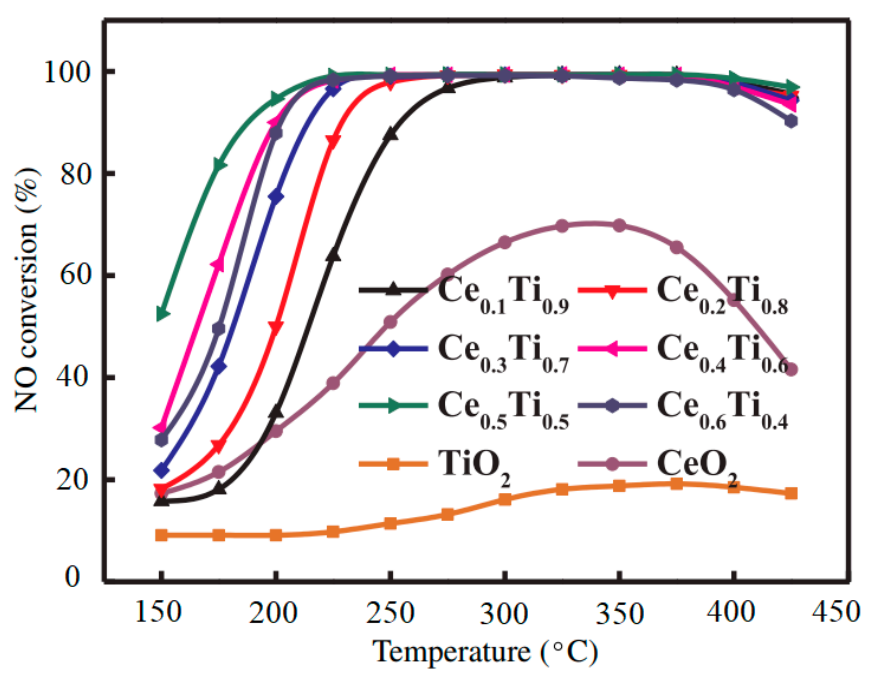

Figure 3. $\mathrm{NH}_{3}-\mathrm{SCR}$ activity of $\mathrm{TiO}_{2}, \mathrm{CeO}_{2}$ and $\mathrm{Ce}_{\mathrm{a}} \mathrm{Ti}_{1-\mathrm{a}}$ catalysts. Conditions: $\left[\mathrm{NH}_{3}\right]=[\mathrm{NO}]=$ $1000 \mathrm{ppm},\left[\mathrm{O}_{2}\right]=3 \mathrm{vol} . \%, \mathrm{~N}_{2}$ as balance gas, total flow rate $=500 \mathrm{~mL} \cdot \mathrm{min}^{-1}$ [39]. 


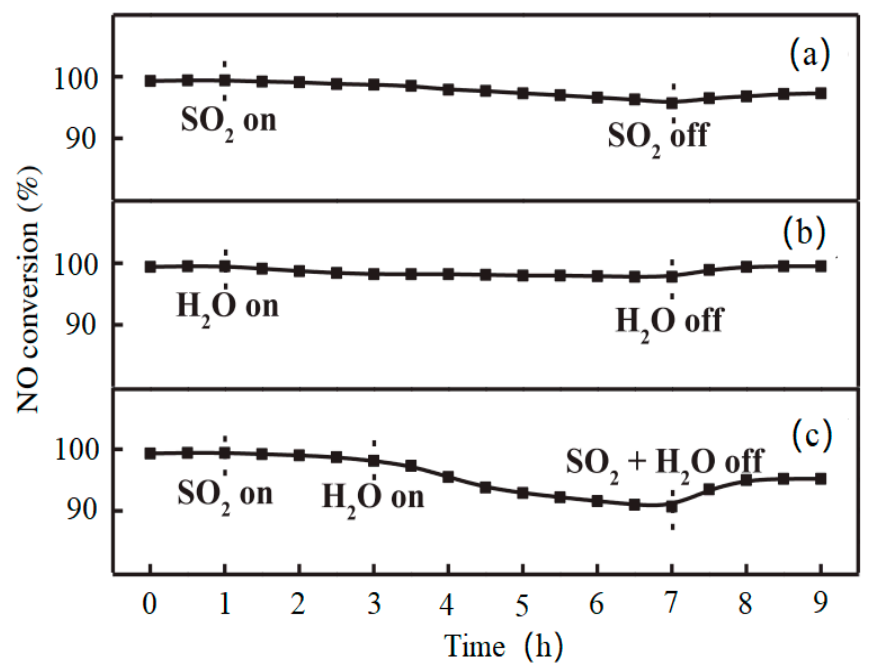

Figure 4. Effect of (a) $\mathrm{SO}_{2}$, (b) $\mathrm{H}_{2} \mathrm{O}$ and (c) $\mathrm{SO}_{2}+\mathrm{H}_{2} \mathrm{O}$ on $\mathrm{NH}_{3}-\mathrm{SCR}$ activity over $\mathrm{Ce}_{0.5} \mathrm{Ti}_{0.5}$ catalyst at $300{ }^{\circ} \mathrm{C}$. Conditions: $\left[\mathrm{NH}_{3}\right]=[\mathrm{NO}]=1000 \mathrm{ppm},\left[\mathrm{SO}_{2}\right]=100 \mathrm{ppm},\left[\mathrm{H}_{2} \mathrm{O}\right]=10 \mathrm{vol} . \%,\left[\mathrm{O}_{2}\right]=3$ vol.\%, $\mathrm{N}_{2}$ as balance gas [39].

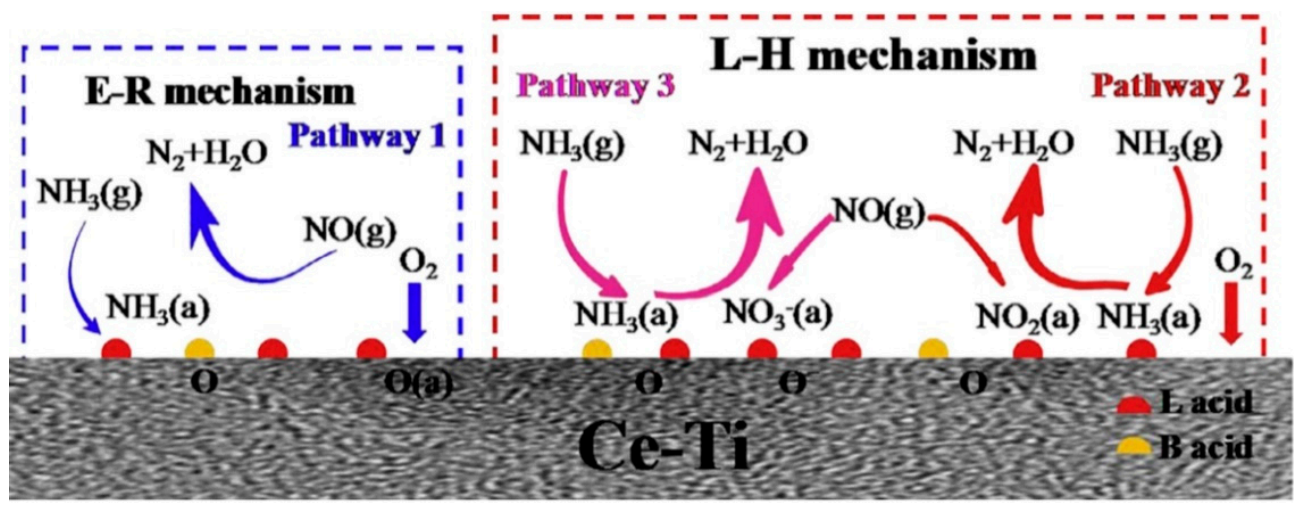

Figure 5. Proposed $\mathrm{NH}_{3}-\mathrm{SCR}$ reaction mechanism over $\mathrm{Ce}_{\mathrm{a}} \mathrm{Ti}_{1-\mathrm{a}}$ catalysts [39].
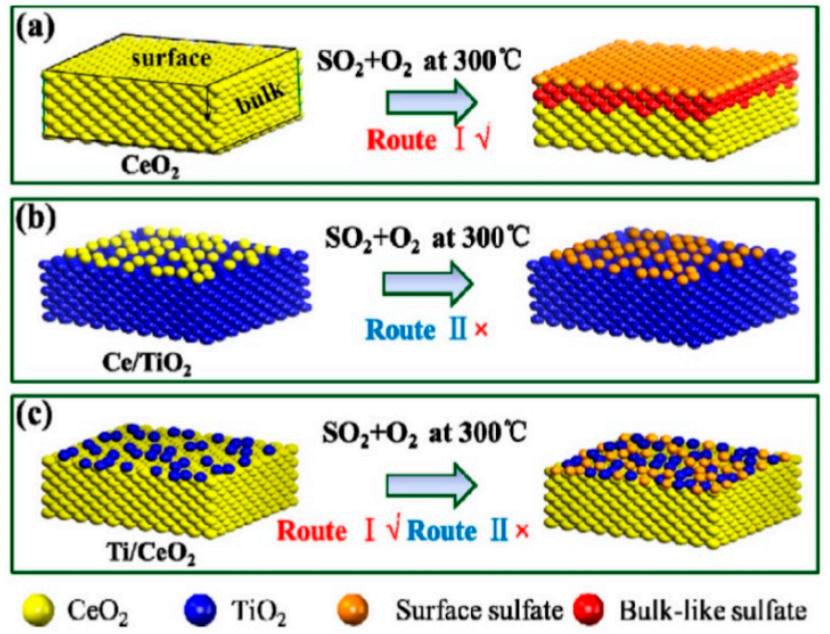

Figure 6. Proposed adsorption model of $\mathrm{SO}_{2}$ : (a) $\mathrm{CeO}_{2},(\mathbf{b}) \mathrm{Ce} / \mathrm{Ti}$ and (c) $\mathrm{Ti} / \mathrm{Ce}[40]$. 


\section{2. $\mathrm{CeO}_{2}-\mathrm{MnO}_{2}$ Catalyst}

Up to now, the Mn-based catalyst has been extensively investigated in the literature. It was found to have superior low temperature activity due to its rich variable valence states ( $\mathrm{MnO}, \mathrm{Mn}_{3} \mathrm{O}_{4}, \mathrm{Mn}_{5} \mathrm{O}_{8}, \mathrm{Mn}_{2} \mathrm{O}_{3}$, and $\mathrm{MnO}_{2}$ ) and huge surface area [43-45]. The presence of the $\mathrm{Mn}^{4+}$ species and its redox process are important for the excellent $\mathrm{NH}_{3}-\mathrm{SCR}$ activity at low temperatures and for $\mathrm{N}_{2}$ selectivity [46-49]. At the same time, the thermal stability, chemisorbed oxygen and the concentration of $\mathrm{O}_{\alpha}$ species on the surface will be improved by $\mathrm{MnO}_{x}$ and $\mathrm{CeO}_{2}$ [50]. However, the obstacle to the application of $\mathrm{Mn}$-based catalysts is the poor performance of resisting $\mathrm{H}_{2} \mathrm{O}$ and $\mathrm{SO}_{2}$ [51]. The addition of $\mathrm{CeO}_{2}$ can enhance resistance to $\mathrm{H}_{2} \mathrm{O}$ and $\mathrm{SO}_{2}$ to a certain extent [52,53]. For example, Qi et al. [54,55] introduced the $\mathrm{CeO}_{2}-\mathrm{MnOx}$, which catalyst showed great $\mathrm{H}_{2} \mathrm{O} / \mathrm{SO}_{2}$ durability. Moreover, $\mathrm{Mn}$ ions entered the lattice of $\mathrm{CeO}_{2}$ and a large number of chemisorbed oxygen species were released to the surface, thereby enhancing the $\mathrm{NH}_{3}$-SCR activity of the catalysts.

Besides, Ce and Mn can present different valence states under suitable preparation methods and reaction conditions. Furthermore, the strong interaction between $\mathrm{CeO}_{2}$ and $\mathrm{MnO}_{2}$ will make the catalysts show excellent low-temperature activity and improve the redox performance of the catalysts. For example, the different preparation methods of the $\mathrm{MnO}_{\mathrm{x}}-\mathrm{CeO}_{2}$ catalyst have been analyzed by Shen et al. [56]. It was demonstrated that the hydrolysis process method suggested higher SCR activity in the temperature range of 80-260 ${ }^{\circ} \mathrm{C}$; meanwhile, this catalyst showed higher $\mathrm{Mn}^{4+} / \mathrm{Mn}^{3+}, \mathrm{Ce}^{4+} / \mathrm{Ce}^{3+} \mathrm{ra}-$ tio, higher specific area and higher $\mathrm{O}_{\mathrm{a}} / \mathrm{O}_{\mathrm{p}}$ ratio. Apart from some mature preparation methods, many researchers have made innovative works about preparation methods; Yao et al. [57] reported that the $\mathrm{MnO}_{\mathrm{x}}-\mathrm{CeO}_{2}$ catalyst prepared by the hydrothermal treatment method revealed the best $\mathrm{NH}_{3}-\mathrm{SCR}$ performance and good resistance to $\mathrm{SO}_{2}$ and $\mathrm{H}_{2} \mathrm{O}$ (Figure 7a,b). The XRD patterns and Raman spectra characterization were shown in Figure $7 c, d$, where it was demonstrated that $\mathrm{CeO}_{2}$ and $\mathrm{MnO}_{\mathrm{x}}$ had a strong interaction under the conditions of high temperature and high pressure. Furthermore, $\mathrm{Mn}^{\mathrm{n}+}$ entered into the lattice of $\mathrm{CeO}_{2}$ to form $\mathrm{Mn}-\mathrm{O}-\mathrm{Ce}$ solid solution, which enhanced the SCR performance of the catalysts. Andreoli et al. [58] prepared $\mathrm{CeO}_{2}-\mathrm{MnO}_{\mathrm{x}}$ catalysts by the solution combustion synthesis method, and this catalyst exhibited a higher $\mathrm{NO}_{x}$ conversion of more than $90 \%$ at $120-350{ }^{\circ} \mathrm{C}$. Besides, Liu et al. [59] synthesized the $\mathrm{MnO}_{\mathrm{x}}-\mathrm{CeO}_{2}$ catalyst by the surfactant-template (ST) method and coprecipitation (CP) method, and the XRD demonstrated that smaller mixed oxide particles were obtained by the surfactant-template method. The smaller particles could contribute to improving the SCR performance, as shown in Figure 8a. Meanwhile, more reducible subsurface and bulk oxygen were clearly observed in the $\mathrm{H}_{2}-\mathrm{TPR}$, as shown in Figure 8b. However, one problem relating to the Mn based catalyst is that its application at low temperature is a big challenge. The main problem is that the $\mathrm{N}_{2}$ selectivity will decrease significantly at high temperature. Meanwhile, the catalytic activity will still be inhibited by $\mathrm{H}_{2} \mathrm{O}$ and $\mathrm{SO}_{2}$, which cannot meet the requirements of industrial production [60]. 

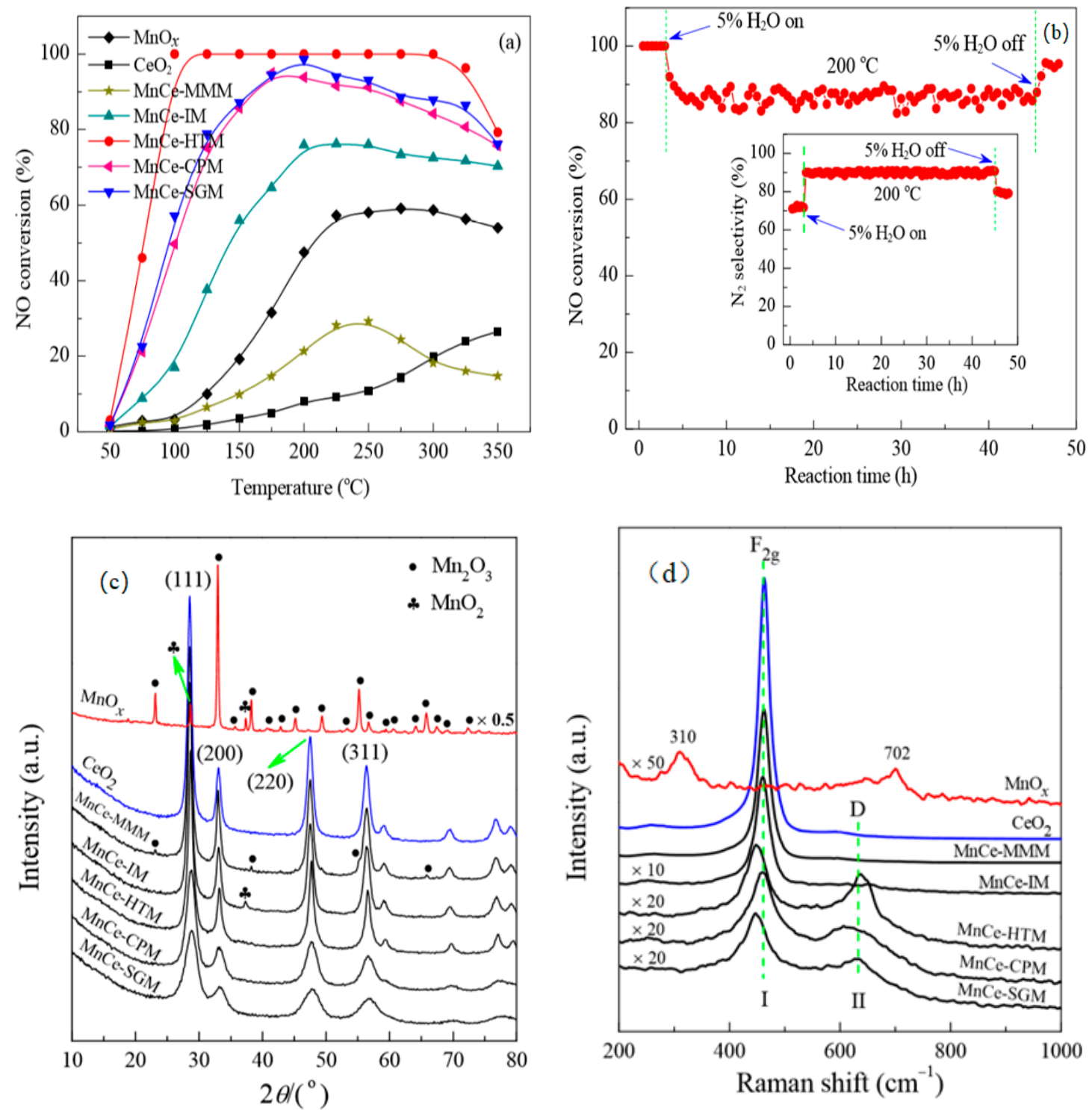

Figure 7. (a) $\mathrm{NO}$ conversion of the synthesized $\mathrm{MnO}_{x}-\mathrm{CeO}_{2}$ catalysts; (b) the $\mathrm{H}_{2} \mathrm{O}$ resistance of MnCe-HTM catalyst at $200{ }^{\circ} \mathrm{C}$; (c) XRD patterns and of the synthesized catalysts and; (d) Raman spectra of the synthesized catalysts [57].
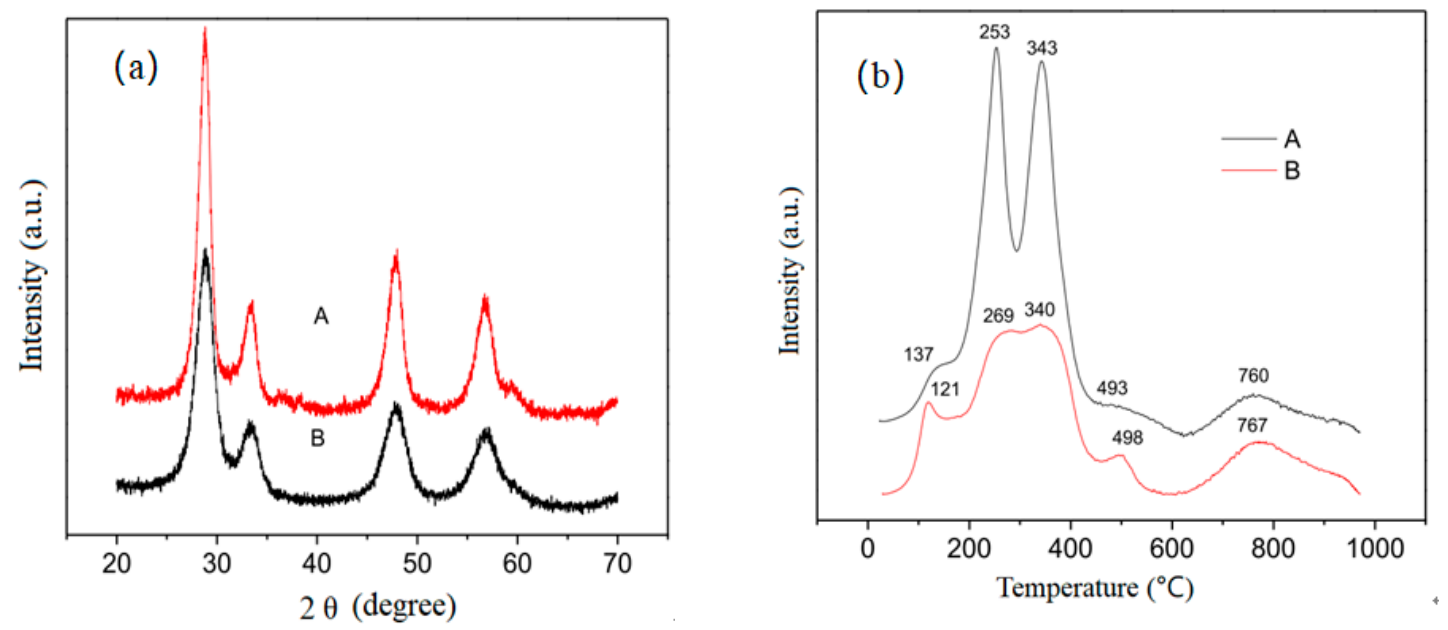

Figure 8. (a) XRD patterns of $\mathrm{Mn}_{5} \mathrm{Ce}_{5}$ (CP) (A) and $\mathrm{Mn}_{5} \mathrm{Ce}_{5}$ (ST) (B) catalysts and (b) $\mathrm{H}_{2}-\mathrm{TPR}$ profiles for $\mathrm{Mn}_{5} \mathrm{Ce} \mathrm{e}_{5}(\mathrm{CP})(\mathrm{A})$ and $\mathrm{Mn}_{5} \mathrm{Ce}_{5}$ (ST) (B) catalysts [59]. 


\subsection{Other $\mathrm{CeO}_{2}-\mathrm{MO}_{x}$ Catalysts}

In addition to the above composite metal oxides, other metal oxides as the main active components in $\mathrm{NH}_{3}$-SCR catalysts have been extensively studied for low-medium temperatures. For example, the addition of $\mathrm{WO}_{3}$ [61,62], $\mathrm{Sn}_{2} \mathrm{O}_{5}$ [63], $\mathrm{MoO}_{3}$ [64], $\mathrm{CuO}_{\mathrm{x}}$ [65] and $\mathrm{NiO}$ [66] into Ce-based catalysts can improve the redox performance, surface acidity and the adsorption of $\mathrm{NH}_{3}$ on the catalyst surface. Meanwhile, the addition of $\mathrm{ZrO}_{2}$ [67], $\mathrm{CoO}$ [68] can enhance the specific surface area, thermal stability and the resistance to $\mathrm{H}_{2} \mathrm{O} / \mathrm{SO}_{2}$ of cerium-based catalysts. The modification of cerium-based catalysts by doping $\mathrm{WO}_{3}$ showed excellent de- $\mathrm{NO}_{x}$ performance. For instance, Wang et al. [61] reported that the $\mathrm{WO}_{3}$ was deposited on $\mathrm{CeO}_{2}$ nanoparticles. This catalyst also exhibited the highest SCR activity below $300{ }^{\circ} \mathrm{C}$, excellent $\mathrm{H}_{2} \mathrm{O} / \mathrm{SO}_{2}$ resistance and good $\mathrm{NH}_{3}$ adsorption at $125-450{ }^{\circ} \mathrm{C}$. Generally, the presence of $\mathrm{WO}_{3}$ provided more surface lattice oxygen $\mathrm{O}^{2-}$ and acid sites at lower temperatures, which benefits the catalytic activity for $\mathrm{NH}_{3}-\mathrm{SCR}$. At the same time, the $\mathrm{CeO}_{2}-\mathrm{WO}_{3}$ catalyst has been reported on by Liu et al. [62]. The results suggested that the presence of $\mathrm{W}$ provided more acid sites, thereby generating additional chemisorbed oxygen, weakly adsorbed oxygen species and concentrations of $\mathrm{Ce}$ and $\mathrm{Ce}^{3+}$ on the surface of the catalyst, shown in Figure 9. Liu et al. [63] investigated the performance of a $\mathrm{CeO}_{2}-\mathrm{SnO}_{2}$ catalyst for $\mathrm{NH}_{3}-\mathrm{SCR}$. The results revealed that the high catalytic performance of this catalyst was attributed to the synergetic effect between Ce and Sn species, which enhanced the redox ability, the Lewis acidity and the adsorption and activation of $\mathrm{NH}_{3}$ species, thereby contributing to improving the $\mathrm{NH}_{3}-\mathrm{SCR}$ performance.
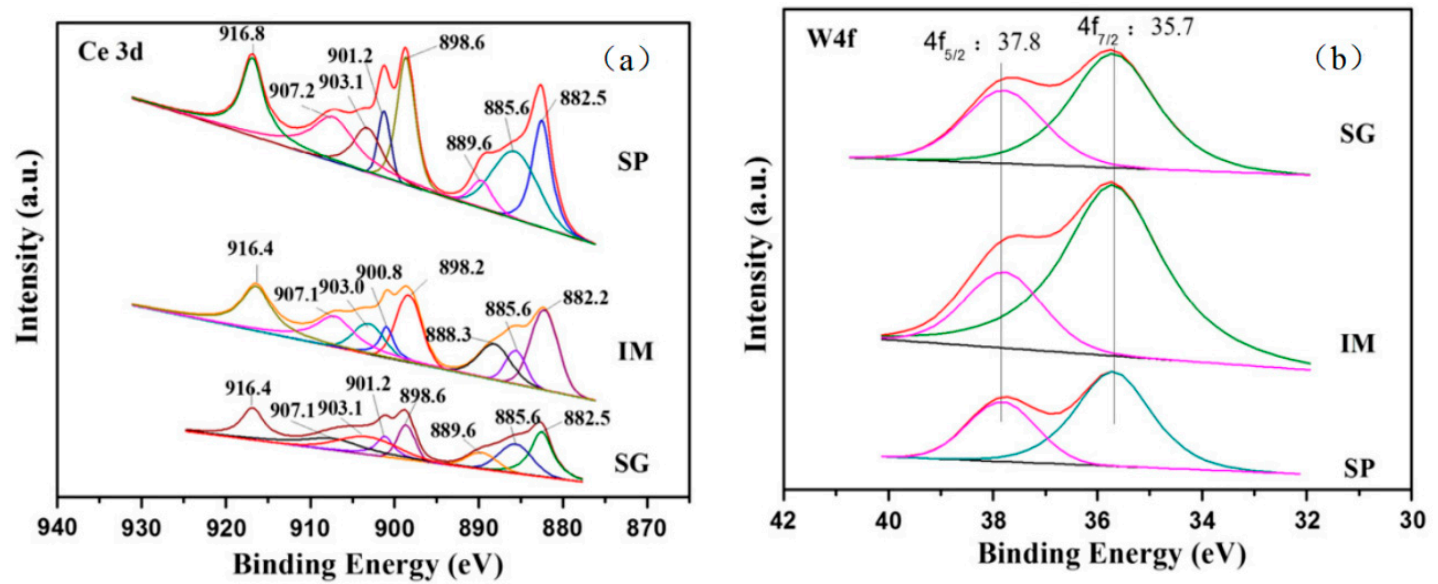

Figure 9. XPS spectra of (a) $\mathrm{Ce} 3 \mathrm{~d}$ and (b) W4f over $\mathrm{CeO}_{2}-\mathrm{WO}_{3}$ catalysts [62].

Besides, the catalytic performance of the $\mathrm{CeO}_{2}-\mathrm{MoO}_{3}$ catalyst has been investigated by Peng et al. [64]. This catalyst showed good $\mathrm{NH}_{3}-\mathrm{SCR}$ performance. Moreover, the $\mathrm{Ce}$ atoms and amorphous $\mathrm{MoO}_{3}$ structure provided a large number of Lewis acid sites and Brönsted acid sites on the catalyst surface. Atribak et al. [67] reported the performance of the $\mathrm{CeO}_{2}-\mathrm{ZrO}_{\mathrm{x}}$ catalyst at high temperature, and the results indicated the addition of $\mathrm{Zr}$ provided excellent thermal stability and more specific surface area of the catalysts. Apart from the traditional $\mathrm{CeO}_{2}-\mathrm{MO}_{\mathrm{x}}$ catalysts, the single-atom catalysts have also showed great potential in the $\mathrm{NH}_{3}$-SCR. Especially, adding a second late-transition metal into cerium-based catalyst as single atom could have great potential in the automobile exhaust field $[69,70]$.

\section{Cerium-Based Multiplex Oxide Catalysts}

Cerium-based multiplex oxide catalysts are particularly outstanding owing to making up for the shortcomings of some single or bimetallic catalysts on $\mathrm{NH}_{3}-\mathrm{SCR}$ activity. For $\mathrm{CeO}_{2} / \mathrm{TiO}_{2}$ catalyst, such as $\mathrm{Mn}, \mathrm{W}$ and $\mathrm{Mo}$ are introduced to further improve the redox performance, the surface acidity and the $\mathrm{H}_{2} \mathrm{O} / \mathrm{SO}_{2}$ durability of the catalysts. Therefore, 
the effects of cerium-based multiplex oxide catalysts on de- $\mathrm{NO}_{x}$ performance were mainly studied from the aspects of preparation methods, preparation conditions and additive doping modification.

\section{1. $\mathrm{Ce}-\mathrm{Mn} / \mathrm{TiO}_{2}$ Catalyst}

Apparently, $\mathrm{MnO}_{\mathrm{x}}$ has many changeable valence states. Its oxides can be converted to each other, which shows excellent catalytic activity at low temperature [71-73]. Meanwhile, $\mathrm{CeO}_{2}$ can reduce the loss of specific surface area and pore volume during calcination, which improves the oxygen storage capacity and redox performance of the catalysts. Besides, the interaction between $\mathrm{MnO}_{\mathrm{x}}$ and $\mathrm{CeO}_{2}$ can form $\mathrm{Mn}-\mathrm{O}-\mathrm{Ce}$ solid solution, thereby improving the adsorption and activation properties of $\mathrm{NH}_{3}$ [74]. For example, Liu et al. [75] developed the $\mathrm{Mn}-\mathrm{Ce} / \mathrm{TiO}_{2}$ catalyst by hydrothermal method. It was also found that the environmentally benign $\mathrm{Mn}-\mathrm{Ce} / \mathrm{TiO}_{2}$ catalyst exhibited excellent $\mathrm{NH}_{3}-\mathrm{SCR}$ activity and good resistance to $\mathrm{H}_{2} \mathrm{O}$ and $\mathrm{SO}_{2}$ with a wide temperature window. Meanwhile, this result showed that the dual redox cycles $\left(\mathrm{Mn}^{4+}+\mathrm{Ce}^{3+} \leftrightarrow \mathrm{Mn}^{3+}+\mathrm{Ce}^{4+}, \mathrm{Mn}^{4+}+\mathrm{Ti}^{3+} \leftrightarrow\right.$ $\mathrm{Mn}^{3+}+\mathrm{Ti}^{4+}$ ) might play a key role in the catalytic reaction, which facilitated the adsorption and activation of $\mathrm{NH}_{3}$, as shown in Figure 10. The structure and properties of $8 \% \mathrm{Mn}-$ $\mathrm{Ce} / \mathrm{TiO}_{2}-\mathrm{PILC}$ catalyst has been analyzed by Shen et al. [76]. The catalyst suggested rich mesoporous structure and large specific surface area. More specifically, it could be demonstrated that $\mathrm{Ce}$ modified $\mathrm{Mn}-\mathrm{Ce} / \mathrm{TiO}_{2}-\mathrm{PILC}$ catalyst enhanced the dispersion of $\mathrm{Mn}$ on the surface.

Redox I

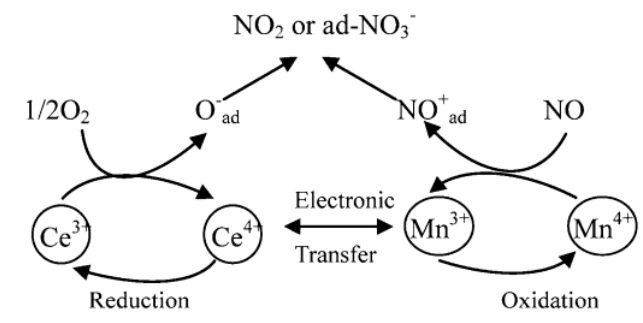

Redox II

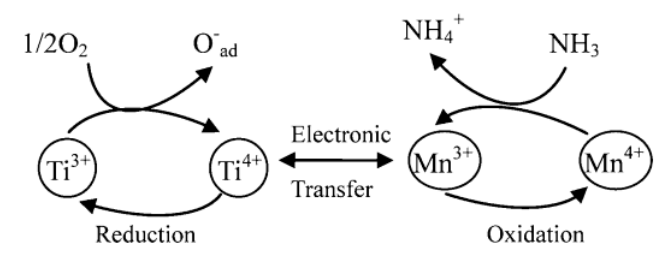

Figure 10. Dual redox cycles for the activation of $\mathrm{NO}$ and $\mathrm{NH}_{3}[70]$.

Compared with $\mathrm{CeO}_{2}-\mathrm{MnO}_{\mathrm{x}}$ catalyst, the resistance to $\mathrm{H}_{2} \mathrm{O}$ and $\mathrm{SO}_{2}$ of the Ce$\mathrm{Mn} / \mathrm{TiO}_{2}$ catalyst has been enhanced to some extent [77]. $\mathrm{CeO}_{2}$ can significantly inhibit the deposition of $\left(\mathrm{NH}_{4}\right)_{2} \mathrm{SO}_{4}$ and $\mathrm{NH}_{4} \mathrm{HSO}_{4}$ on the catalyst surface, which is the fundamental reason for the improvement of $\mathrm{SO}_{2} / \mathrm{H}_{2} \mathrm{O}$ resistance [78]. For instance, that $\mathrm{SO}_{2}$ poisoning and regeneration of the $\mathrm{Mn}-\mathrm{Ce} / \mathrm{TiO}_{2}$ catalyst have been reported by Sheng et al. [79]. This catalyst showed good resistance to $\mathrm{SO}_{2}$; however, the deactivation of the $\mathrm{Mn}-\mathrm{Ce} / \mathrm{TiO}$ poisoned by $\mathrm{SO}_{2}$ still occurred. Then, Peng et al. [80] reported the influence of Ce addition on the potassium poisoning of the $\mathrm{MnO}_{\mathrm{x}} / \mathrm{TiO}_{2}$ catalyst, and found that $\mathrm{K}$ can reduce the surface acidity and reduction performance of the catalyst. However, the presence of $\mathrm{CeO}_{2}$ can provide a certain number of Lewis acid sites, shown in Figure 11a; meanwhile, $\mathrm{CeO}_{2}$ enhanced the reducibility of $\mathrm{Mn} / \mathrm{Ti}$ and maintained the redox performance of the SCR catalysts after potassium poisoning, shown in Figure 11b. 

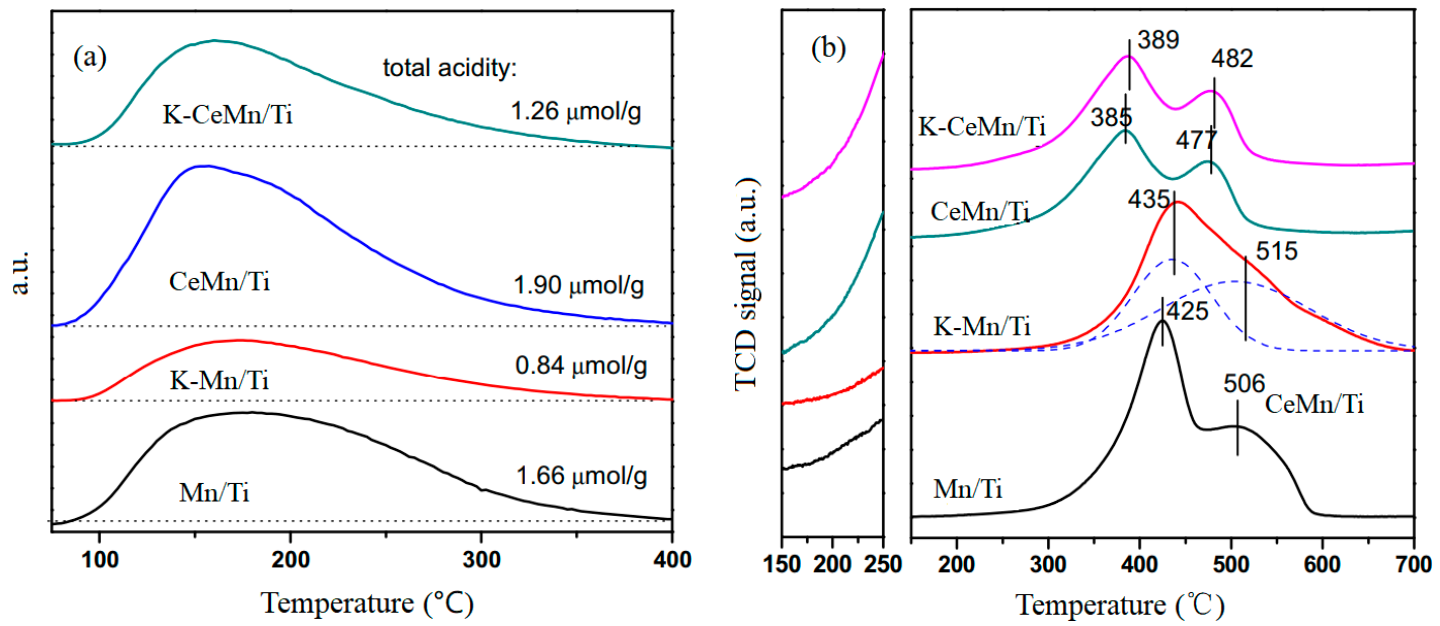

Figure 11. (a) $\mathrm{NH}_{3}$-TPD profiles of fresh and poisoned catalysts in the range of $75-400{ }^{\circ} \mathrm{C}$ and (b) $\mathrm{H}_{2}$-TPR profiles of fresh and poisoned catalysts in the range of $150-700{ }^{\circ} \mathrm{C}[80]$.

Eventually, from the reported work on the $\mathrm{Ce}-\mathrm{Mn} / \mathrm{TiO}_{2}$ catalyst, it is not difficult to find that the rich variable valence states of $\mathrm{Mn}$ show excellent $\mathrm{NH}_{3}$-SCR activity at low temperature. However, its SCR performance resistance to $\mathrm{H}_{2} \mathrm{O} / \mathrm{SO}_{2}$ still needs to be further strengthened.

\section{2. $\mathrm{Ce}-\mathrm{W} / \mathrm{TiO} \mathrm{O}_{2}$ Catalyst}

Apparently, different aspects of $\mathrm{W}$ modified cerium-based catalysts have been widely studied, and highly dispersed $\mathrm{WO}_{3}$ is beneficial to improve the catalytic effect of the whole catalyst $[81,82] . \mathrm{WO}_{3}$, as a stabilizer and promoter, significantly increased the specific surface area, $\mathrm{Ce}^{3+} / \mathrm{Ce}^{4+}$ ratio and surface acid sites of the catalysts, consequently enhancing the adsorbed oxygen on the surface and the activated oxygen species $[83,84]$. Firstly, Chen et al. [85] developed $\mathrm{Ce} / \mathrm{TiO}_{2}$ and $\mathrm{W}-\mathrm{Ce} / \mathrm{TiO}_{2}$ catalysts by the impregnation method. They also found that $\mathrm{W}-\mathrm{Ce} / \mathrm{TiO}_{2}$ catalyst showed better de-NO performance. As shown in Figure 12, the presence of $\mathrm{W}$ provided more acid sites on the catalyst surface, and accelerated the reaction between $\mathrm{NH}_{4} \mathrm{NO}_{3}$ and $\mathrm{NO}$ to achieve a superior low-temperature activity. Then, Guo et al. [86] found that the $\mathrm{CeO}_{2}-\mathrm{WO}_{3} / \mathrm{TiO}_{2}$ catalyst showed good catalytic activity. Pretreated $\mathrm{TiO}_{2}$ made the surface active substances have higher dispersion. The addition of $\mathrm{WO}_{3}$ also enhanced the surface acidity and surface chemisorption oxygen. Meanwhile, the influence of $\mathrm{WO}_{3}$ intervention on the catalytic performance of $\mathrm{MnCeW} / \mathrm{m}$ $\mathrm{TiO}_{2}$ catalyst has been investigated by Zha et al. [87]. This catalyst showed excellent deNO performance and $\mathrm{N}_{2}$ selectivity under the conditions of wide temperature window and high space velocity. Particularly, in in situ DRIFTs, as shown in Figure 13, it found that the addition of $\mathrm{WO}_{3}$ enhanced more Brönsted acid sites on the surface at high temperature. Additionally, some researchers have reported some innovative preparation methods. For example, Katarzyna et al. [88] prepared $\mathrm{WO}_{3} / \mathrm{CeO}_{\mathrm{x}}-\mathrm{TiO}_{2}$ catalyst by the flame-spray synthesis method, and Figure 14 suggests the interpretation of the mechanism of particle formation during flame-spray synthesis method. This method further strengthened the interaction of $\mathrm{WO}_{3}, \mathrm{CeO}_{2}$ and $\mathrm{TiO}_{2}$. Meanwhile, the presence of $\mathrm{WO}_{3}$ increased $\mathrm{Ce}^{3+}$ and surface acidity on the catalyst surface to a great extent. The highly dispersed $\mathrm{WO}_{3}$ enhanced the $\mathrm{Ce}-\mathrm{O}-\mathrm{W}$ reaction and $\mathrm{Ce}-\mathrm{O}-\mathrm{Ti}$ reaction, and consequently improved the performance of the $\mathrm{NH}_{3}$-SCR catalysts. Besides, the addition of $\mathrm{WO}_{3}$ improved the thermal stability of the catalysts at $550-600{ }^{\circ} \mathrm{C}$ [89], and a large cerium oxide phase and more $\mathrm{TiO}_{2}$ crystal formation can be avoided in the catalytic reaction process [90]. 


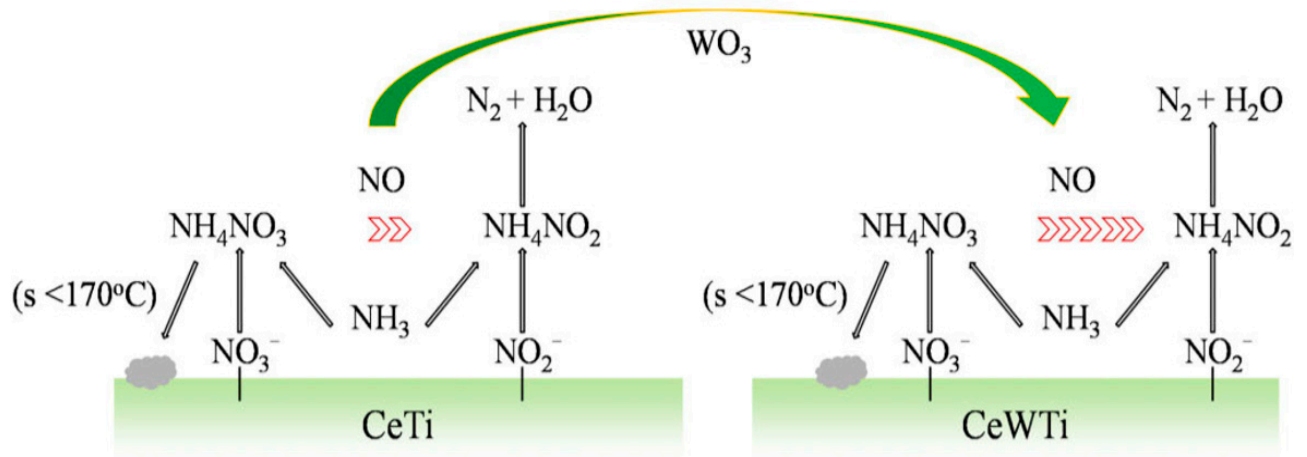

Figure 12. $\mathrm{NH}_{3}-\mathrm{NO} / \mathrm{NO}_{2} \mathrm{SCR}$ reaction routes on CeTi and CeWTi catalysts [85].
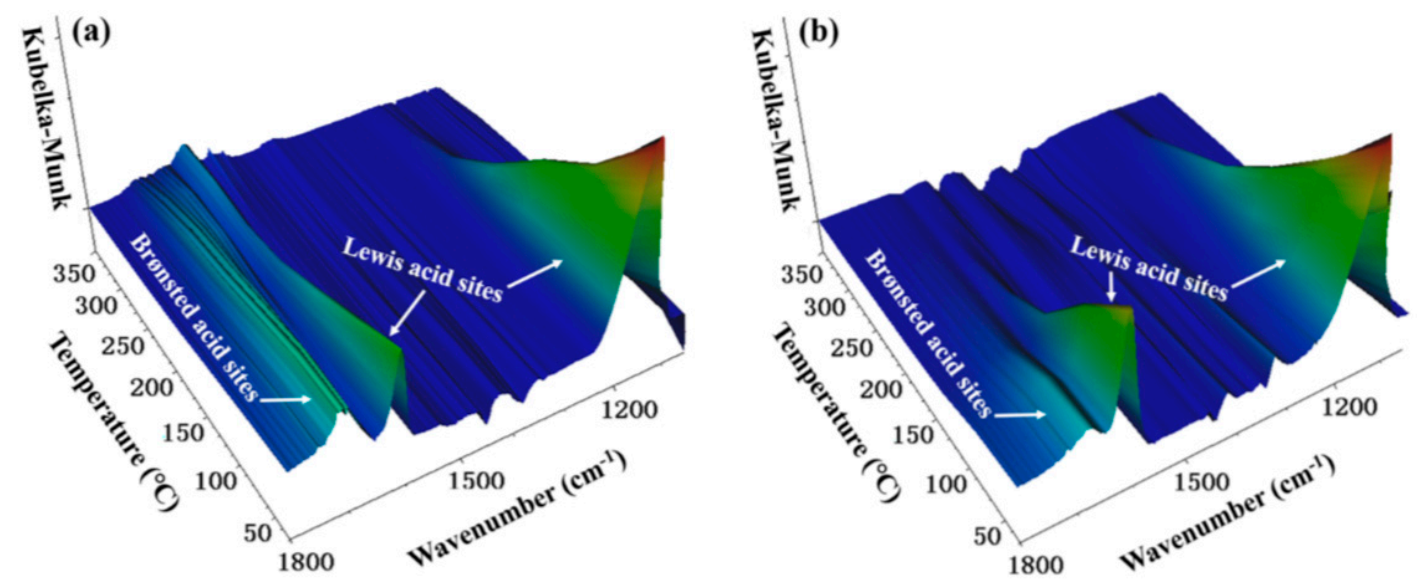

Figure 13. In situ DRIFTs of $\mathrm{NH}_{3}$ desorption over (a) $\mathrm{MnCeW} / \mathrm{m}-\mathrm{TiO}_{2}$ and (b) $\mathrm{MnCe} / \mathrm{m}-\mathrm{TiO}_{2}$ catalysts as a function of temperature [87].

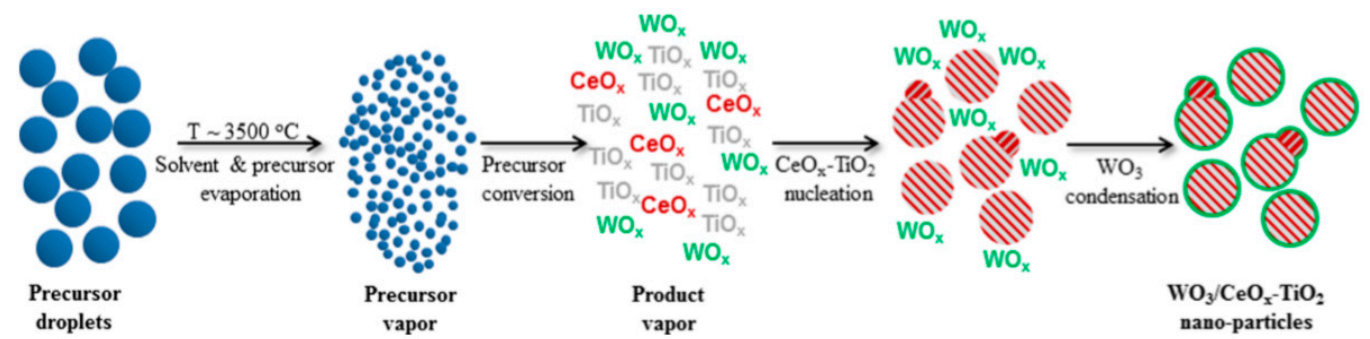

Figure 14. Schematic representation of a feasible mechanism of $\mathrm{WO}_{3} / \mathrm{CeO}_{\mathbf{x}}-\mathrm{TiO}_{2}$ nanoparticles formation during flamespray synthesis [88].

Generally, the ratio of $\mathrm{CeO}_{2}$ and $\mathrm{WO}_{3}$ has great effect on the redox ability and surface characteristics of $\mathrm{Ce}-\mathrm{W} / \mathrm{TiO}_{2}$ catalysts, which also determines the $\mathrm{NH}_{3}$-SCR performance. For instance, the $\mathrm{Ce}_{0.2} \mathrm{~W}_{0.2} \mathrm{Ti}$ catalyst with Ce/W molar ratio of $1: 1$ has been synthesized by Shan et al. [91]. It also showed that the best $\mathrm{NH}_{3}$-SCR catalytic performance and $100 \% \mathrm{~N}_{2}$ selectivity; above $90 \%$ of $\mathrm{NO}$ conversion was maintained from $275^{\circ} \mathrm{C}$ to $450{ }^{\circ} \mathrm{C}$. Besides, in our previous research, we have done some work on the $\mathrm{Ce}-\mathrm{W} / \mathrm{TiO}_{2}$ catalyst for the $\mathrm{NH}_{3}$-SCR reaction and analyzed the influence of the active components $\mathrm{CeO}_{2}$ and $\mathrm{WO}_{3}$ content on the de- $\mathrm{NO}_{x}$ performance of the catalysts, and found that the $30 \mathrm{Ce} 4 \mathrm{~W} / \mathrm{TiO}_{2}$ catalyst showed up to $90 \% \mathrm{NO}_{x}$ conversion at the widest temperature range of $310{ }^{\circ} \mathrm{C}$. More specifically, the results show that a higher proportion of $\mathrm{Ce}^{4+}$, more chemisorption of oxygen and high specific surface area were key for the excellent $\mathrm{NH}_{3}-\mathrm{SCR}$ activity of this catalyst [92]. 


\section{3. $\mathrm{Ce}-\mathrm{Mo} / \mathrm{TiO}_{2}$ Catalyst}

Undoubtedly, it is not difficult to find that the addition of Mo can remarkably improve the performance of SCR catalysts. Especially, $\mathrm{CeO}_{2}$ and $\mathrm{MoO}_{3}$ can be highly dispersed on the surface of $\mathrm{TiO}_{2}$ carrier. Furthermore, Mo doping increases the $\mathrm{Ce}^{3+}$ content, creates more abundant Brönsted acid sites, and increases the oxygen vacancy and adsorbed oxygen substances on the catalyst surface [93,94]. Additionally, the presence of $\mathrm{MoO}_{3}$ could effectively enhance the $\mathrm{SO}_{2}$ and $\mathrm{H}_{2} \mathrm{O}$ resistance of the catalysts at low temperature [95]. For example, $\mathrm{Li}$ et al. [96] prepared an $\mathrm{Mo}$-doped $\mathrm{MoO}_{3} / \mathrm{CeO}_{2}-\mathrm{TiO}_{2}\left(\mathrm{MoO}_{3} / \mathrm{CT}\right)$ catalyst. The catalyst showed good low temperature activity and excellent $\mathrm{SO}_{2} / \mathrm{H}_{2} \mathrm{O}$ resistance performance (Figure 15a,b). More specifically, the addition of $\mathrm{MoO}_{3}$ increased the Brönsted acid sites on the catalyst surface, shown in Figure 16. Then, the influence of $\mathrm{MoO}_{3}$ modified $\mathrm{CeO}_{2}-\mathrm{TiO}_{2}$ catalyst on the $\mathrm{NH}_{3}$-SCR performance was systematically investigated by $\mathrm{Liu}$ et al. [97],, who suggested that having more Brönsted acid sites was conducive to the adsorption of $\mathrm{NH}_{3}$. Furthermore, $\mathrm{MoO}_{3}$ can inhibit the formation of sulfates; thereby the catalyst simultaneously showed excellent $\mathrm{SO}_{2} / \mathrm{H}_{2} \mathrm{O}$ resistance. Besides, Ye et al. [98] prepared $\mathrm{CeO}_{2}-\mathrm{MoO}_{3} / \mathrm{TiO}_{2}$ catalysts by different kinds of methods, and found that the catalyst prepared by sol-gel method exhibited the widest reaction temperature window of $250-475^{\circ} \mathrm{C}$.
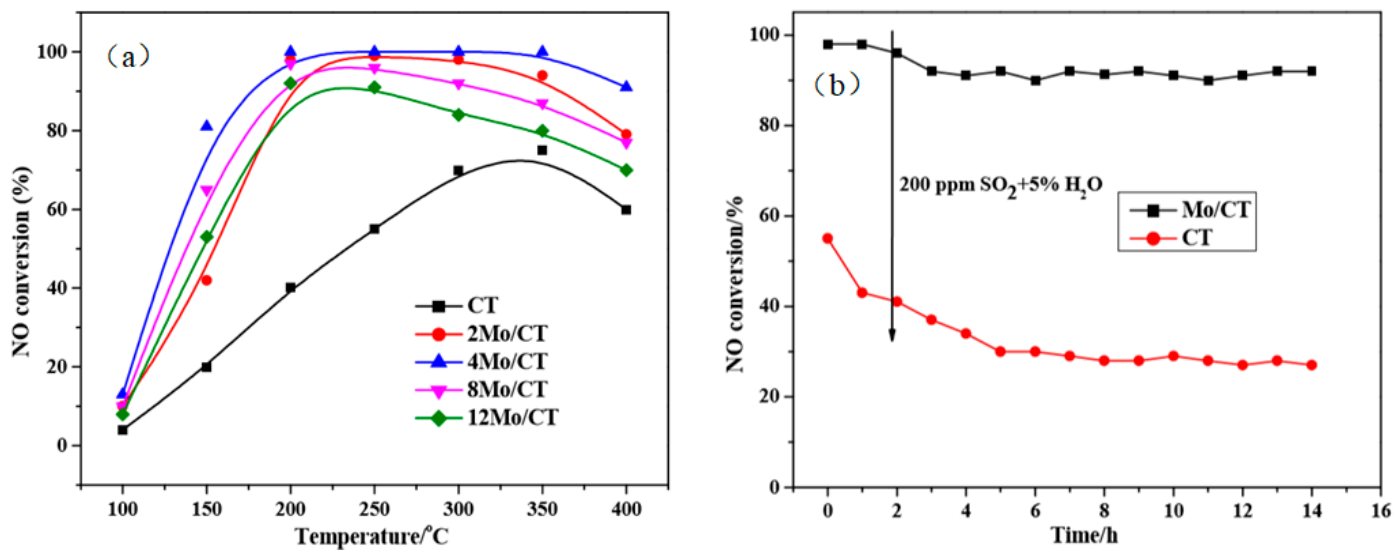

Figure 15. (a) $\mathrm{NO}$ conversions on these $\mathrm{MoO}_{3} / \mathrm{CeO}_{2}-\mathrm{TiO}_{2}(\mathrm{Mo} / \mathrm{CT})$ catalysts with different $\mathrm{Mo}$ and (b) $\mathrm{H}_{2} \mathrm{O}+\mathrm{SO}_{2}$ resistance of the $\mathrm{CeO}_{2}-\mathrm{TiO}_{2}(\mathrm{CT})$ and $\mathrm{Mo} / \mathrm{CT}$ catalysts at $250{ }^{\circ} \mathrm{C}$ [96].
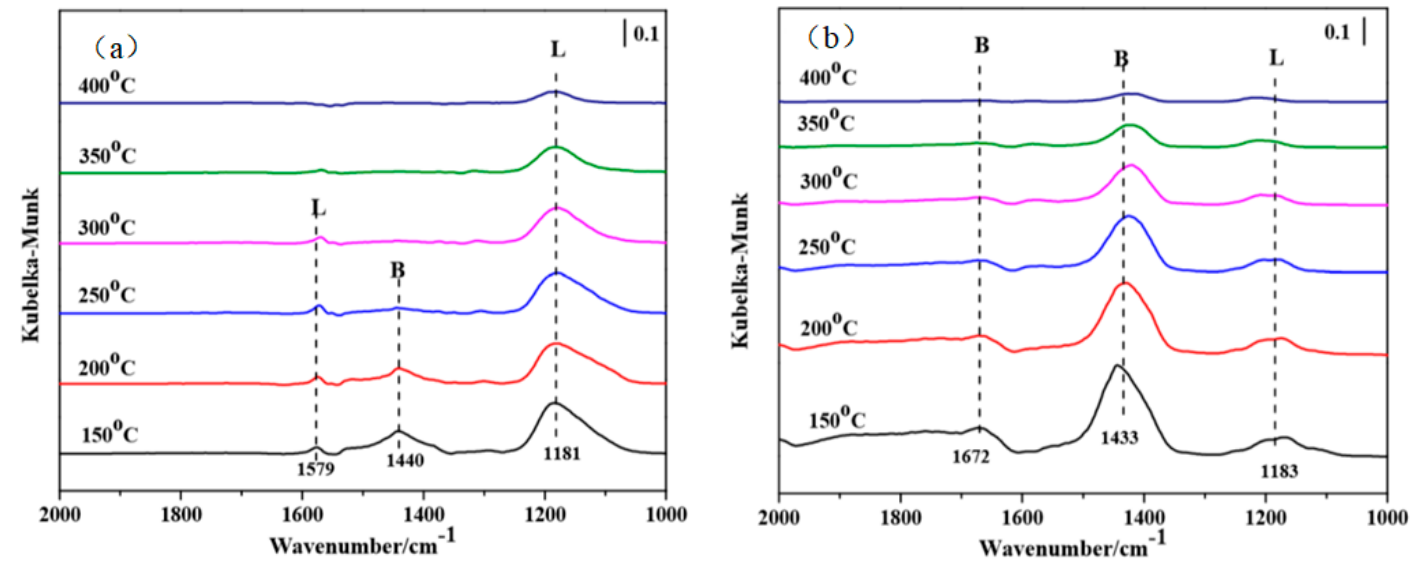

Figure 16. $\mathrm{NH}_{3}$ adsorption in situ DRIFTS of (a) $\mathrm{CeO}_{2}-\mathrm{TiO}_{2}(\mathrm{CT})$ and (b) $\mathrm{MoO}_{3} / \mathrm{CeO}_{2}-\mathrm{TiO}_{2}(\mathrm{Mo} / \mathrm{CT})$ catalyst [96] .

Additionally, some researchers added active components to $\mathrm{CeO}_{2}-\mathrm{MoO}_{3} / \mathrm{TiO}_{2}$ catalysts to enhance the deNO $\mathrm{N}_{x}$ performance of the catalyst. For instance, the $\mathrm{NH}_{3}-\mathrm{SCR}$ performance of a new type of $\mathrm{CeO}_{2}-\mathrm{MoO}_{3}-\mathrm{WO}_{3} / \mathrm{TiO}_{2}$ catalyst has been reported by Jiang 
et al. [99]. The result exhibited that the NO conversion was 93.8 98.9\% at a GHSV of $90,000 \mathrm{~h}^{-1}$ and a temperature window of $275-450{ }^{\circ} \mathrm{C}$. The presence of $\mathrm{WO}_{3}$ and $\mathrm{MoO}_{3}$ increased the adsorption capacity of $\mathrm{NH}_{3}$, the redox performance, the amount of $\mathrm{Ce}^{3+}$ and the chemisorption of oxygen on the surface. At the same time, the interaction between $\mathrm{CeO}_{2}$, $\mathrm{MoO}_{3}, \mathrm{WO}_{3}$ and $\mathrm{TiO}_{2}$ might play an increasingly vital role in the improvement of catalytic performance. Zhang et al. [100] developed the catalytic performance of the $\mathrm{CeFMoTiO}_{\mathrm{x}}$ catalyst, which not only exhibited higher than $90 \%$ NO conversion at $240-420{ }^{\circ} \mathrm{C}$, but also presented superior $\mathrm{H}_{2} \mathrm{O} / \mathrm{SO}_{2}$ durability. The results demonstrated that the presence of $\mathrm{MoO}_{3}$ improved the dispersity of $\mathrm{CeO}_{2}$ on the catalyst surface. The introduction of $\mathrm{F}$ increased the oxygen vacancy, consequently improved the redox performance of $\mathrm{CeO}_{2}$. Meanwhile, the Ti-F bond played a key role in the SCR reaction. Eventually, the poisoning mechanism of As on $\mathrm{CeO}_{2}-\mathrm{MoO}_{3} / \mathrm{TiO}_{2}$ catalyst has been analyzed by Li et al. [101], as shown in Figure 17. The results exhibited that $\mathrm{As}_{2} \mathrm{O}_{5}$ would directly weaken the specific surface area, surface acidity and redox performance. However, after the addition of Mo, the stronger interaction between Mo and As can alleviate the effects of surface $\mathrm{CeO}_{2}$ poisoning to a certain extent, so as to recover the redox performance and Brönsted acid sites of the $\mathrm{CeO}_{2}-\mathrm{MoO}_{3} / \mathrm{TiO}_{2}$ catalyst.

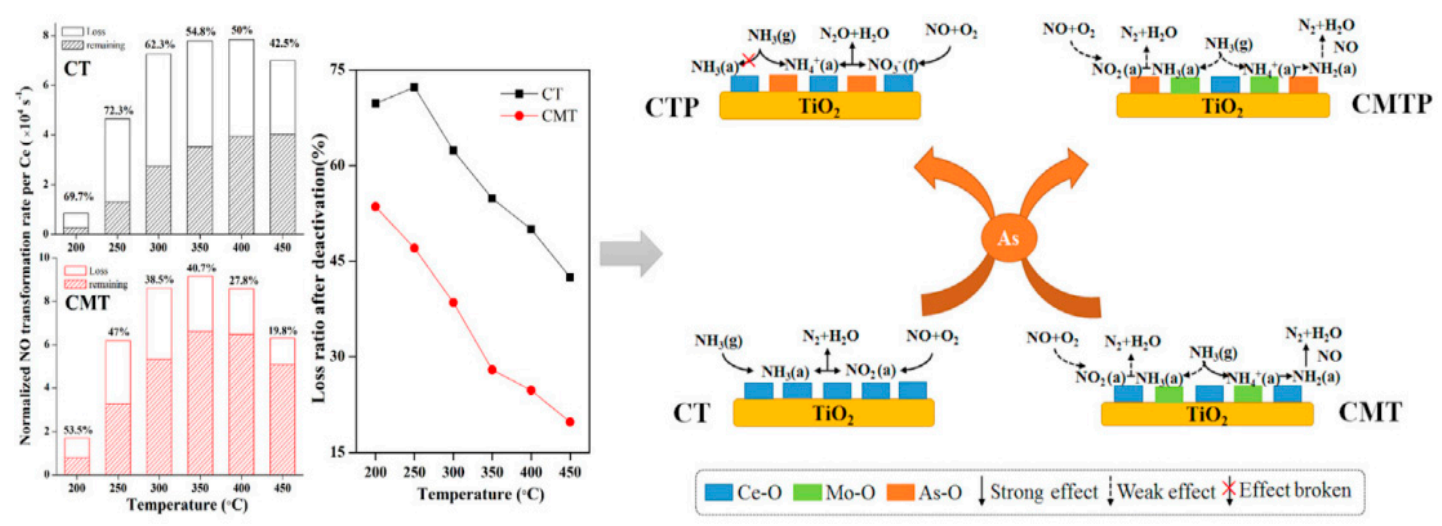

Figure 17. The performance of the arsenic resistance on $\mathrm{MoO}_{3}$ doped $\mathrm{CeO}_{2} / \mathrm{TiO}_{2}$ catalyst for SCR of $\mathrm{NO}_{\mathrm{x}}$ with ammonia [101].

\subsection{Other Cerium-Based Multiplex Oxide Catalysts}

In addition to the above multiplex oxide catalysts, many research papers have reported that $\mathrm{CeO}_{2}$ was combined with other transition metal oxides to form $\mathrm{NH}_{3}-\mathrm{SCR}$ catalysts, such as $\mathrm{Sn}_{2} \mathrm{O}_{5}$ [102], $\mathrm{VO}_{x}$ [103], $\mathrm{CuO}$ [104], $\mathrm{Nb}_{2} \mathrm{O}_{5}$ [105], $\mathrm{ZrO}_{2}$ [106] and $\mathrm{CoO}$ [107]. They can simultaneously enhance the surface acidity, redox performance and $\mathrm{SO}_{2} / \mathrm{H}_{2} \mathrm{O}$ resistance of the SCR catalysts. For instance, Zhang et al. [97] prepared $\mathrm{CeSnTiO}_{\mathrm{x}}$ catalysts by the solvothermal method. The results suggest that the Sn doped catalysts showed better low-temperature activity, exhibiting an extraordinarily wide operation window ranging from 180 to $460{ }^{\circ} \mathrm{C}$. Meanwhile, the $\mathrm{H}_{2}$-TPR and XPS spectra results verified that the addition of $\mathrm{Sn}_{2} \mathrm{O}_{5}$ improved the interaction between $\mathrm{CeO}_{2}$ and $\mathrm{SnO}_{2}$ and the redox ability of the catalysts. Then, a novel $\mathrm{V}_{2} \mathrm{O}_{5} / \mathrm{CeTiO}_{x}$ catalyst was introduced by Lian et al. [103]. The addition of $\mathrm{VO}_{\mathrm{x}}$ enhanced catalytic activity, $\mathrm{N}_{2}$ selectivity and the resistance to $\mathrm{SO}_{2}$ and $\mathrm{H}_{2} \mathrm{O}$. Then, $\mathrm{Li}$ et al. [104] studied $\mathrm{Cu}$ modified $\mathrm{Ce} / \mathrm{TiO}_{2}$ catalyst, and found that the catalyst with a $\mathrm{Cu} / \mathrm{Ce}$ molar ratio of 0.005 showed the best low-temperature activity and excellent $\mathrm{SO}_{2}$ resistance performance. By means of XRD, BET, Raman, XPS and $\mathrm{NH}_{3}$ TPD, it was demonstrated that the presence of $\mathrm{CuO}$ increased the amount of the surface adsorbed oxygen and $\mathrm{Ce}^{3+}$ species and created more Brönsted acid sites on the catalyst surface. Furthermore, the in situ DRIFT results demonstrated that $\mathrm{CuO}$ doping enhanced the adsorption capacity of $\mathrm{NH}_{3}$. 
Besides, Jawaher et al. [105] prepared $\mathrm{Nb}_{5}-\mathrm{Ce}_{40} / \mathrm{Ti}_{10}$ catalyst by sol-gel method, and found that the catalyst showed up to $95 \% \mathrm{NO}_{x}$ conversion at $200{ }^{\circ} \mathrm{C}$. The addition of $\mathrm{Nb}$ strengthened the surface acidity. Meanwhile, the strong interaction between $\mathrm{Ce}$ and $\mathrm{Ti}$ to form the $\mathrm{Ce}-\mathrm{O}-\mathrm{Ti}$ solid solution and the high dispersion of $\mathrm{Nb}_{2} \mathrm{O}_{5}$ can improve the $\mathrm{NH}_{3}$-SCR activity. However, the presence of $\mathrm{Nb}_{2} \mathrm{O}_{5}$ will greatly decrease the specific surface area of the catalysts. Then, $\mathrm{Zr}$ modified $\mathrm{Ce}-\mathrm{W} / \mathrm{TiO}_{\mathrm{x}}$ catalyst was analyzed by Zhao et al. [106]. The presence of $\mathrm{Zr}$ enhanced more acidic sites, oxygen vacancies and adsorbed oxygen species on the surface, which showed the best $\mathrm{NH}_{3}$-SCR catalytic activity and thermal stability. Liu et al. [107] found that the $\mathrm{Co}-\mathrm{Ce} / \mathrm{TiO}_{2}$ catalyst exhibited good low-temperature activity, widened the temperature window and reacted quickly under the mechanism of L-H and E-R. Furthermore, the different particle sizes of $\mathrm{Co}^{2+}$ and $\mathrm{Ce}^{4+}$ promoted the $\mathrm{Ce}^{3+}$ ratio and surface adsorption oxygen. Besides, Li et al. [108] prepared Ho-doped $\mathrm{Mn}-\mathrm{Ce} / \mathrm{TiO}_{2}$ catalyst by impregnation method. The results indicated that the catalyst with $\mathrm{Ho} / \mathrm{Ti}$ of 0.1 presented excellent catalytic activity with the $\mathrm{NO}$ conversion of more than $90 \%$ at $140-220^{\circ} \mathrm{C}$ (Figure $18 \mathrm{a}, \mathrm{b}$ ). The characterization results showed that Ho increased the specific surface area and led to higher levels of chemisorbed oxygen, as shown in Figure 19; meanwhile, the presence of Ho inhibited the sulfation on the surface to some extent.
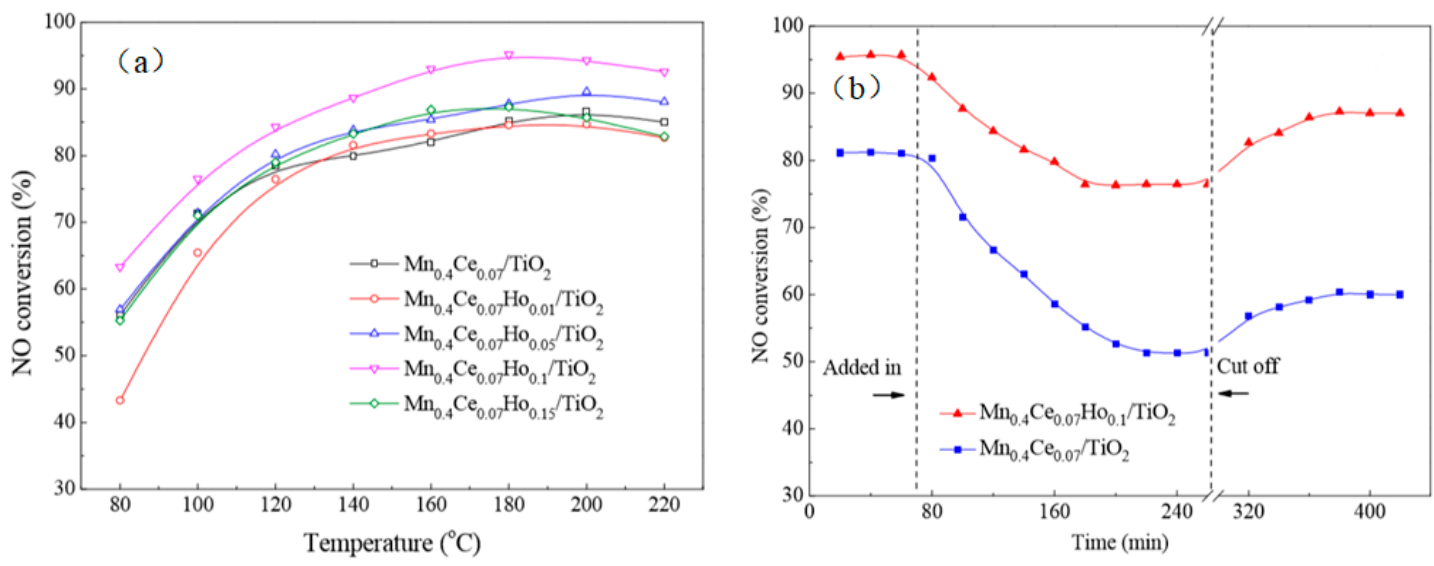

Figure 18. (a) Comparison of catalytic performance of different catalysts and (b) effect of $\mathrm{SO}_{2}+\mathrm{H}_{2} \mathrm{O}$ on $\mathrm{NO}$ conversion over $\mathrm{Mn}_{0.4} \mathrm{Ce}_{0.07} / \mathrm{TiO}_{2}$ and $\mathrm{Mn}_{0.4} \mathrm{Ce}_{0.07} \mathrm{Ho}_{0.1} / \mathrm{TiO}_{2}$ catalysts [108]. 


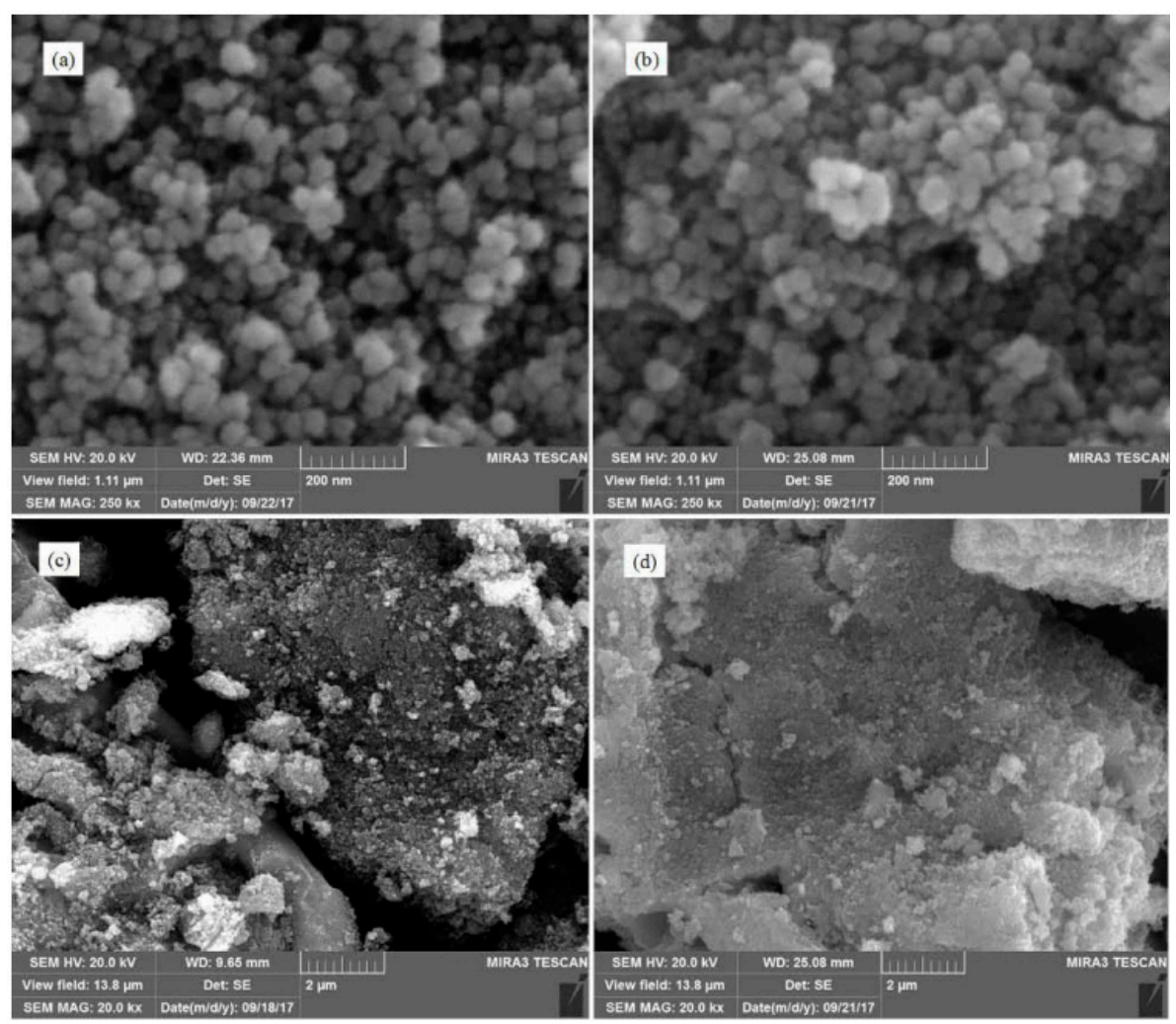

Figure 19. SEM images of two catalysts (a) $\mathrm{Mn}_{0.4} \mathrm{Ce}_{0.07} \mathrm{Ho}_{0.1} / \mathrm{TiO}_{2}$, (b) $\mathrm{Mn}_{0.4} \mathrm{Ce}_{0.07} / \mathrm{TiO}_{2}$, (c) $\mathrm{Mn}_{0.4} \mathrm{Ce}_{0.07} \mathrm{Ho}_{0.1} / \mathrm{TiO}_{2}$ and (d) $\mathrm{Mn}_{0.4} \mathrm{Ce}_{0.07} / \mathrm{TiO}_{2}$ [108].

\section{Molecular Sieve Catalysts}

Apart from the ceria-based composite oxide SCR catalysts, the excellent activity and high $\mathrm{N}_{2}$ selectivity of molecular sieves are also considered as the most promising SCR catalysts $[109,110]$. Especially, molecular sieve catalyst has strong stability, toxicity resistance and wide reaction temperature range [111]. Among the molecular sieve catalysts, ZSM-5, Beta, USY and other carriers exhibit good adsorption capacity, moderate surface acidity and flexible reaction temperature window. Peculiarly, ZSM-5 exhibits stable crystal structure, good specific surface area, abundant acid sites and great thermal stability [112-114]. For example, Krishna K et al. [115] prepared the Ce/ZSM-5 catalyst by ion exchange method. The results suggested that $\mathrm{CeO}_{2}$ is closely bound to $\mathrm{ZSM}-5$, which provided more active sites to transform $\mathrm{NO}_{x}$. Then, Liu et al. [116] prepared $\mathrm{CeO}_{2}$-modified $\mathrm{Cu} / \mathrm{ZSM}-5$ catalyst by a wetness impregnation method, and found the presence of $\mathrm{CeO}_{2}$ enhanced the $\mathrm{NH}_{3}$ SCR activity of the catalyst at low temperature. However, this catalyst had a poor catalytic performance at high temperature. Additionally, Dou [117] analyzed that the addition of Ce can inhibit the crystallization of $\mathrm{Cu}$ and increase the dispersion of active component, which made the catalyst show better de- $\mathrm{NO}_{x}$ performance at $148-427^{\circ} \mathrm{C}$. The $\mathrm{Fe}-\mathrm{ZSM}-5 @ \mathrm{CeO}_{2}$ catalyst has been investigated by $\mathrm{Chen}$ et al. [118]. The catalyst showed excellent $\mathrm{NH}_{3}-\mathrm{SCR}$ activity and $\mathrm{N}_{2}$ selectivity, mainly due to the construction strategy of Fe-ZSM-5@CeO to increase the redox performance and active oxygen species of the catalyst, shown in Figure 20. Subsequently, the surface $\mathrm{Ce}^{4+}$ and active oxygen species over Fe-ZSM-5@CeO promoted the adsorption and activation of NO, shown in Figure 21. Carja et al. [119] studied the $\mathrm{Mn}-\mathrm{Ce} / \mathrm{ZSM}-5$ catalyst and the results exhibited good $\mathrm{NH}_{3}-\mathrm{SCR}$ activity in the presence of $\mathrm{H}_{2} \mathrm{O}$ and $\mathrm{SO}_{2}$. More importantly, the synergistic interaction of ZSM-5 and Ce, Mn promoted microporous-mesoporous characteristics and specific surface properties of catalysts. Besides, Liu et al. [120] reported $\mathrm{CuCe}_{0.75} \mathrm{Zr}_{0.25} \mathrm{Oy} / \mathrm{ZSM}-5$ catalyst. The reaction temperature window was widened to $175-468{ }^{\circ} \mathrm{C}$. According to XRD and TEM results, the 
presence of $\mathrm{Zr}$ increased the dispersion of $\mathrm{Cu}$ and inhibited the crystallization of $\mathrm{Cu}$, and XPS and $\mathrm{H}_{2}$-TPR analysis demonstrated that $\mathrm{Cu}$ ions entered the lattice of $\mathrm{ZrO}_{2}$ or $\mathrm{CeO}_{2}$.

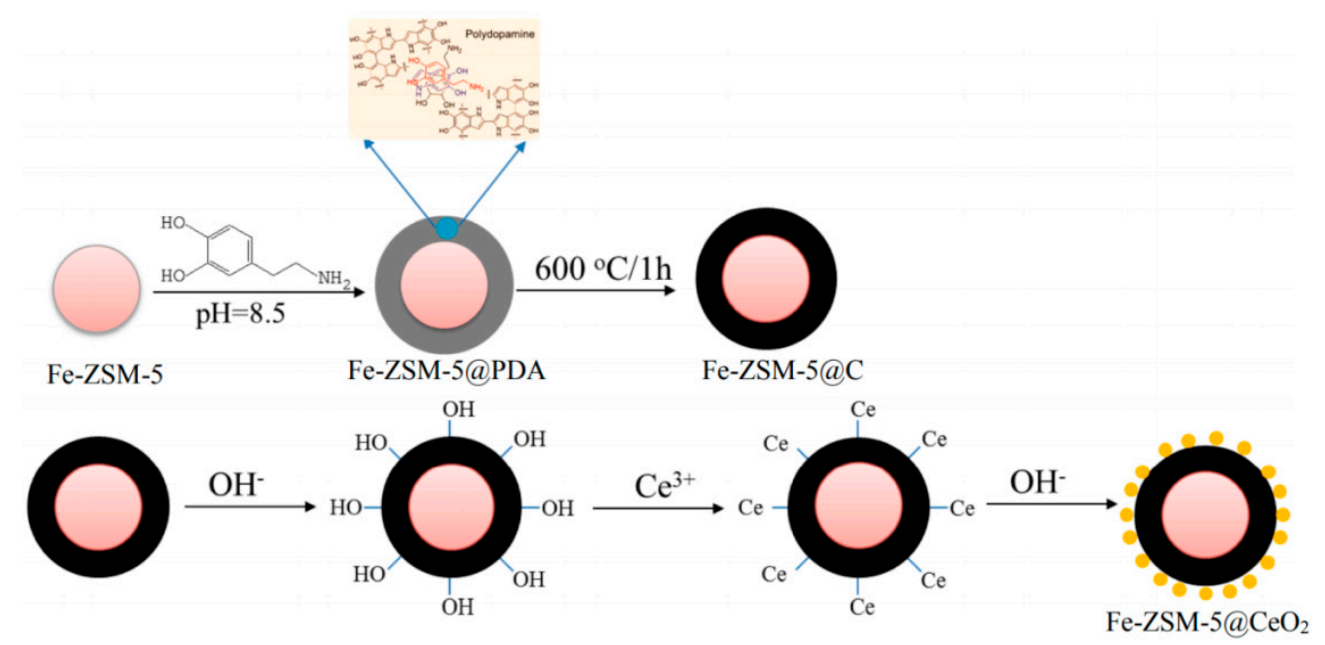

Figure 20. The PDA (Personal Digital Assistant)-assisted route for Fe-ZSM-5@CeO 2 preparation [118].

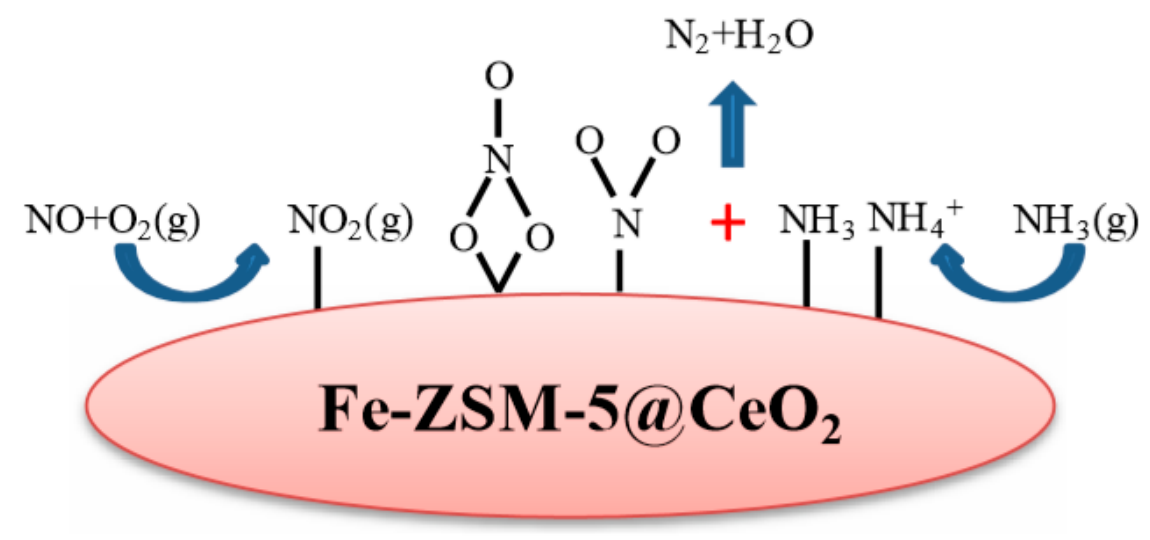

Figure 21. The proposed mechanism of $\mathrm{NH}_{3}-\mathrm{SCR}$ over Fe-ZSM-5@CeO $\mathrm{C}_{2}$ [118].

In addition, both the $\beta$ and USY zeolite catalysts have been mentioned slightly less often than the ZSM-5 zeolite catalyst. However, there are still some valuable studies to be found; for example, Liu et al. [121] reported the coating of $\mathrm{CeO}_{2}$ shells on the surface of MoFe/Beta catalyst, as shown in Figure 22, and found that the presence of the $\mathrm{CeO}_{2}$ shells enhanced the resistance to $\mathrm{SO}_{2}$ and $\mathrm{H}_{2} \mathrm{O}$ and high thermal stability. This was mainly due to the fact that both chemisorbed oxygen species and specific surface area were increased after the coating of the $\mathrm{CeO}_{2}$ shells (Figures 23 and 24). Then, Huang et al. [122] reported Mn-Ce catalysts with $\beta, Z S M-5$ and USY molecular sieves as carriers, respectively, by the impregnation method and studied the de- $\mathrm{NO}_{x}$ performance of the catalysts at low temperature. The results showed that the three zeolite supported Mn-Ce catalysts have good low temperature activity, and the Mn-Ce/USY catalyst showed up to $90 \% \mathrm{NO}_{x}$ conversion at $107^{\circ} \mathrm{C}$. The $\mathrm{MnO}_{\mathrm{x}}$ is mainly distributed on the catalyst surface in an amorphous structure. Meanwhile, the weak acid on the catalyst surface played a major role in the reaction. 


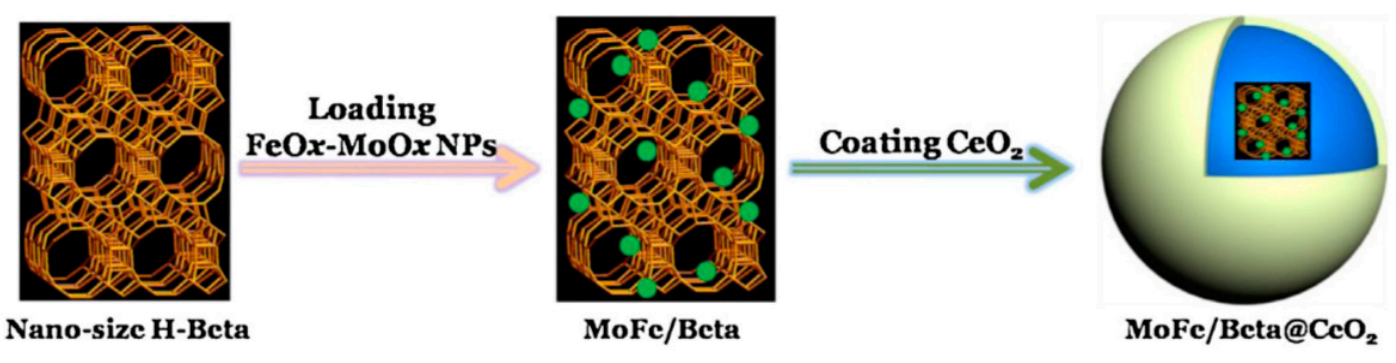

Figure 22. Schematic illustration of the formation of $\mathrm{MoFe} /$ Beta@ $\mathrm{CeO}_{2}$ core-shell catalyst [121].

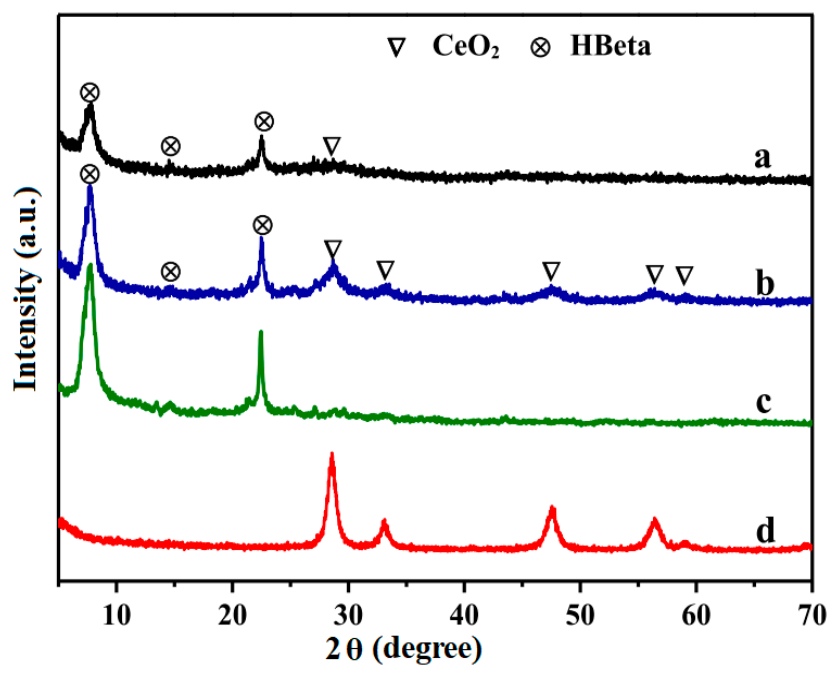

Figure 23. XRD patterns of the catalysts: (a) $\mathrm{MoFe} / \mathrm{Beta} @ \mathrm{CeO}_{2}$, (b) $\mathrm{CeMoFe} / \mathrm{Beta}$, (c) $\mathrm{MoFe} / \mathrm{Beta}$ and (d) $\mathrm{CeO}_{2}$ [121].

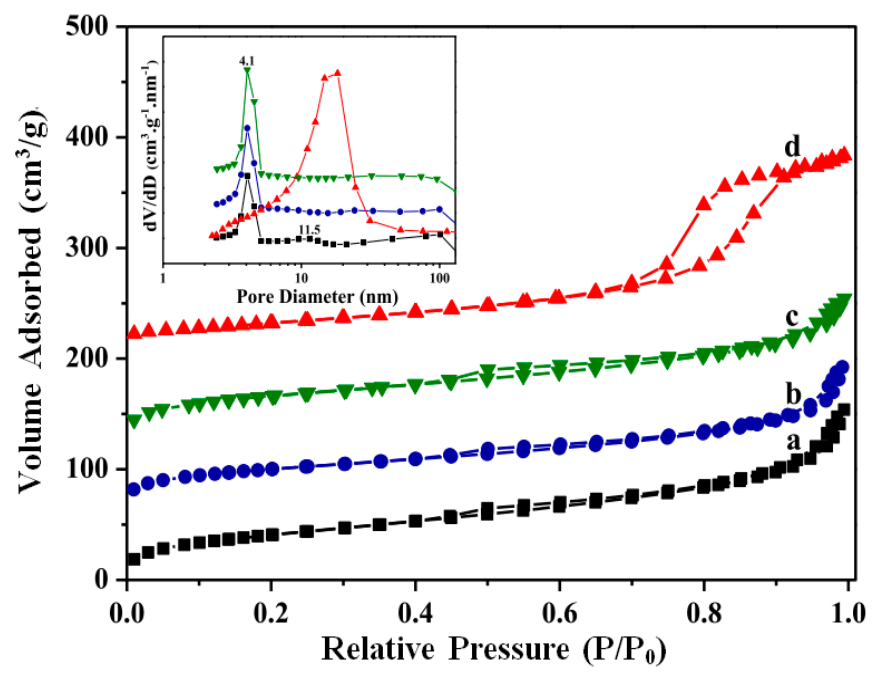

Figure 24. (A) Nitrogen adsorption-desorption isotherms and (B) the size distribution curves of the catalysts: (a) $\mathrm{MoFe} /$ Beta@ $\mathrm{CeO}_{2}$, (b) $\mathrm{CeMoFe} /$ Beta, (c) $\mathrm{MoFe} /$ Beta and (d) $\mathrm{CeO}_{2}$ [121].

Finally, it is worth considering that the addition of active components and promoters can increase redox property for cerium-based SCR catalysts. Furthermore, the oxidation reaction of the catalysts was enhanced. However, the oxidation of $\mathrm{SO}_{2}$ was simultaneously increased in the catalytic reaction process, thereby resulting in the formation of sulfate on the surface and inhibiting the $\mathrm{NH}_{3}-\mathrm{SCR}$ activity of the catalysts. Therefore, the question 
of the resistance to $\mathrm{SO}_{2}, \mathrm{H}_{2} \mathrm{O}$ needs to be further investigated. Finally, for all the above types of catalysts, the denitration performance of the catalysts under different preparation methods and conditions was described in Table 1.

Table 1. The denitration performance of different catalysts.

\begin{tabular}{|c|c|c|c|c|c|}
\hline Catalysts & Method & $\begin{array}{l}\text { Temperature } \\
\text { Window } /{ }^{\circ} \mathrm{C}\end{array}$ & $\begin{array}{c}\mathrm{NO}_{x} \\
\text { Conversion/\% }\end{array}$ & $\begin{array}{l}\text { Gas Hourly Space Velocity } \\
\text { (GHSV)/h }{ }^{-1}\end{array}$ & Refs. \\
\hline $\mathrm{CeO}_{2} / \mathrm{TiO}_{2}$ & Sol-gel & $300-400$ & $93-98 \%$ & $50,000 \mathrm{~h}^{-1}$ & {$[31,32]$} \\
\hline $\mathrm{CeO}_{2} / \mathrm{TiO}_{2}$ & Dry ball milling & 180 & $84.6 \%$ & GHSV of $30,000 \mathrm{~h}^{-1}$ & {$[34]$} \\
\hline $\mathrm{MnO}_{\mathrm{x}}-\mathrm{CeO}_{2}$ & One-step hydrolysis process & 180 & Over $90 \%$ & GHSV of $30,000 \mathrm{~h}^{-1}$ & [53] \\
\hline $\mathrm{CeO}_{2}-\mathrm{WO}_{3}$ & Two-step hydrothermal impregnation & $300-450$ & $100 \%$ & GHSV of $60,000 \mathrm{~h}^{-1}$ & [58] \\
\hline $\mathrm{CeO}_{2}-\mathrm{SnO}_{2}$ & Hydrothermal & $280-425$ & Over $90 \%$ & GHSV of $128,000 \mathrm{~h}^{-1}$ & {$[60]$} \\
\hline $\mathrm{Mn}-\mathrm{Ce} / \mathrm{TiO}_{2}$ & Hydrothermal & $150-350$ & Over $90 \%$ & GHSV of $64,000 \mathrm{~h}^{-1}$ & [70] \\
\hline $\mathrm{Ce}-\mathrm{W} / \mathrm{TiO}_{2}$ & Sol-gel precipitation & $210-460$ & Over $90 \%$ & GHSV of $150,000 \mathrm{~h}^{-1}$ & [81] \\
\hline $\mathrm{Ce}-\mathrm{Mo} / \mathrm{TiO}_{2}$ & Sol-gel & $250-475$ & Over $90 \%$ & GHSV of $90,000 \mathrm{~h}^{-1}$ & {$[94]$} \\
\hline $\mathrm{MnCeW} / \mathrm{TiO}_{2}$ & Impregnation & $140-340$ & Over $95 \%$ & GHSV of $40,000 \mathrm{~h}^{-1}$ & [83] \\
\hline $\mathrm{Ce}-\mathrm{Cu} / \mathrm{ZSM}-5$ & Wet impregnation & $210-320$ & Over $90 \%$ & GHSV of $100,000 \mathrm{~h}^{-1}$ & [112] \\
\hline $\begin{array}{c}\mathrm{MoFe} / \text { Beta@ } \\
\mathrm{CeO}_{2}\end{array}$ & Wet impregnation & $225-600$ & Over $90 \%$ & GHSV of $50,000 \mathrm{~h}^{-1}$ & [117] \\
\hline
\end{tabular}

\section{Conclusions and Perspectives}

In conclusion, cerium-based catalysts have been deeply studied due to their high deNO$_{x}$ performances and low costs. The catalytic performance of cerium-based catalysts mainly depends on surface acidity, specific surface area, redox performance and resistance to $\mathrm{H}_{2} \mathrm{O}$ and $\mathrm{SO}_{2}$. The current study indicated the better catalytic performance of cerium-based bimetallic oxides than pure $\mathrm{CeO}_{2}$ in $\mathrm{NH}_{3}-\mathrm{SCR}$. Furthermore, the multiplex oxide catalysts present a wider operation temperature widow and great low-temperature activity than the bimetallic oxide catalysts. This is attributed to the synergistic interaction between active components and promoters, the enhancement of the acid sites and the redox properties. Moreover, not only the addition of the other metal oxides can modify the performance of cerium-based catalysts, but different synthesis methods can also enhance the dispersion of the active species and the interaction of the different active components, the cerium-based bimetallic oxide catalysts, the cerium-based multiplex oxide catalysts and cerium-based molecular sieve catalysts are still the research directions in $\mathrm{NH}_{3}-\mathrm{SCR}$ field in the future. Some researchers have done fruitful work in the fields of the synthesis method, modification and catalytic mechanism of cerium-based catalysts. Nevertheless, some aspects need to be further investigated. First of all, at low temperature, the performance of catalysts is still inhibited by $\mathrm{H}_{2} \mathrm{O}$ and $\mathrm{SO}_{2}$. Due to that, the improvement of the $\mathrm{SO}_{2} / \mathrm{H}_{2} \mathrm{O}$ resistance of cerium-based catalysts is still the main research direction. Secondly, traditional synthesis methods of catalysts need to be further studied and new synthesis methods need to be explored in order to expose more active sites on the catalyst surface and enhance the interaction between the active components. Furthermore, in order to provide the excellent performance of cerium-based catalysts, it is necessary to further achieve the optimal ratio of the active components. Additionally, for the cost of the catalysts, some metal oxides have high costs, which cause substantial obstacles to their actual production. Therefore, to ensure the excellent catalytic performance of cerium-based catalysts, the active components with low costs should be selected.

Author Contributions: M.C., X.B.: literature search, writing-original draft preparation and editing; F.X., W.W., P.C.: writing-review and editing; X.B., F.X.: funding acquisition. All authors have read and agreed to the published version of the manuscript.

Funding: The work described above was supported by the Major State Basic Research Development Program of China (973 Program) (no. 2012CBA01205) and National Natural Science Foundation of China (no. 51274060).

Data Availability Statement: The data presented in this review are from published sources. 
Conflicts of Interest: The authors declare no conflict of interest.

\section{References}

1. China's Ministry of Environmental Protection. Announcement on the release of the "Second National Census of Pollution Sources". 2018. Available online: http:/ / www.mee.gov.cn/xxgk2018/xxgk/xxgk01/ (accessed on 5 March 2021).

2. Kompio, P.G.W.A.; Brückner, A.; Hipler, F.; Auer, G.; Löffler, E.; Grünert, W. A new view on the relations between tungsten and vanadium in $\mathrm{V}_{2} \mathrm{O}_{5} \mathrm{WO}_{3} / \mathrm{TiO}_{2}$ catalysts for the selective reduction of $\mathrm{NO}$ with $\mathrm{NH}_{3}$. J. Catal. 2012, 286, 237-247. [CrossRef]

3. Lietti, L.; Alemany, J.L.; Forzatti, P.; Busca, G.; Ramis, G.; Giamello, E.; Bregani, F. Reactivity of $\mathrm{V}_{2} \mathrm{O}_{5}-\mathrm{WO}_{3} / \mathrm{TiO}_{2}$ catalysts in the selective catalytic reduction of nitric oxide by ammonia. Catal. Today 1996, 29, 143-148. [CrossRef]

4. Herrmann, J.M.; Disdier, J. Electrical properties of $\mathrm{V}_{2} \mathrm{O}_{5}-\mathrm{WO}_{3} / \mathrm{TiO}_{2}$ EUROCAT catalysts evidence for redox process in selective catalytic reduction (SCR) deNOx reaction. Catal. Today 2000, 56, 389-401. [CrossRef]

5. Kwon, D.W.; Park, K.H.; Ha, H.P.; Hong, S.C. The role of molybdenum on the enhanced performance and $\mathrm{SO}_{2}$ resistance of V/Mo-Ti catalysts for $\mathrm{NH}_{3}$-SCR. Appl. Surf. Sci. 2019, 481, 1167-1177. [CrossRef]

6. Liu, Y.; Zhao, J.; Lee, J.M. Conventional and New Materials for Selective Catalytic Reduction (SCR) of $\mathrm{NO}_{\mathrm{x}}$. ChemCatChem 2018, 10, 1499-1511. [CrossRef]

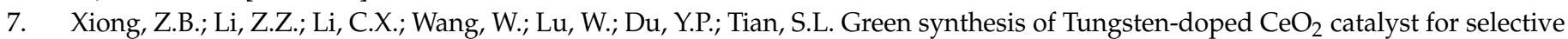
catalytic reduction of $\mathrm{NO}_{x}$ with $\mathrm{NH}_{3}$ using starch bio-template. Appl. Surf. Sci. 2021, 536, 147719. [CrossRef]

8. Wu, W.Y.; Bian, X. Rare Earth Metallurgy Technology; Science Press: Beijing, China, 2012; pp. 1-277. ISBN 978-7-03-032698-0.

9. Qian, J.J.; Li, G.P. The development status of China's rare earth industry. Rare Met. 2003, 6, 813-818.

10. Sarli, V.D.; Landi, G.; Lisi, L.; Benedetto, A.D. Ceria-coated diesel particulate filters for continuous regeneration. AIChE J. 2017, 63, 3442-3449. [CrossRef]

11. Sarli, V.D.; Landi, G.; Benedetto, A.D.; Lisi, L. Synergy between Ceria and Metals (Ag or Cu) in Catalytic Diesel Particulate Filters: Effect of the Metal Content and of the Preparation Method on the Regeneration Performance. Top. Catal. 2020. [CrossRef]

12. Liu, S.; Sun, M.M.; Lin, Q.J.; Xu, H.; Wang, J.; Chen, Y. The promotion effects of $\mathrm{TiO}_{2}$ on the selective catalytic reduction of $\mathrm{NO}_{x}$ with $\mathrm{NH}_{3}$ over $\mathrm{CeO}_{2}-\mathrm{WO}_{3} / \mathrm{ZrO}_{2}$ : The catalytic performance and reaction route. Can. J. Chem. Eng. 2018, 97, 1274-1282. [CrossRef]

13. Tang, C.J.; Zhang, H.L.; Dong, L. Ceria-based catalysts for low-temperature selective catalytic reduction of $\mathrm{NO}$ with $\mathrm{NH}_{3}$. Catal. Sci. Technol. 2016, 6, 1248-1264. [CrossRef]

14. Khan, M.N.; Han, L.; Wang, P.; He, J.; Zhang, D. $\mathrm{SO}_{2}$-tolerant $\mathrm{NO}_{\mathrm{x}}$ reduction over ceria-based catalysts: Shielding effects of hollandite Mn-Ti oxides. Chem. Eng. J. 2020, 397, 125535. [CrossRef]

15. Xu, W.Q.; Yu, Y.B.; Zhang, C.B.; He, H. Selective catalytic reduction of $\mathrm{NO}$ by $\mathrm{NH}_{3}$ over a Ce/ $\mathrm{TiO}_{2}$ catalyst. Catal. Commun. 2008, 9, 1453-1457. [CrossRef]

16. Xu, J.Q.; Chen, G.R.; Guo, F.; Xie, J. Development of wide-temperature vanadium-based catalysts for selective catalytic reducing of $\mathrm{NO}_{x}$ with ammonia: Review. Chem. Eng. J. 2017, 353, 507-518. [CrossRef]

17. Geng, Y.; Jin, K.; Mei, J.; Su, G.Y.; Ma, L.; Yang, S.J. $\mathrm{CeO}_{2}$ grafted with different heteropoly acids for selective catalytic reduction of $\mathrm{NO}$ with $\mathrm{NH}_{3}$. J. Hazard. Mater. 2020, 382, 121032. [CrossRef] [PubMed]

18. Yang, S.J.; Guo, Y.F.; Chang, H.Z.; Ma, L.; Peng, Y.; Qu, Z.; Yan, N.; Wang, C.; Li, J. Novel effect of $\mathrm{SO}_{2}$ on the $\mathrm{SCR}$ reaction over $\mathrm{CeO}_{2}$ : Mechanism and significance. Appl. Catal. B Environ. 2013, 136-137, 19-28. [CrossRef]

19. Lian, Z.H.; Shan, W.P.; Wang, M.; He, H.; Feng, Q.C. The balance of acidity and redox capability over modified $\mathrm{CeO}_{2}$ catalyst for the selective catalytic reduction of $\mathrm{NO}$ with $\mathrm{NH}_{3}$. J. Environ. Sci. 2019, 79, 273-279. [CrossRef] [PubMed]

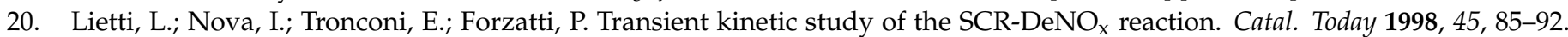
[CrossRef]

21. Feng, X.; Cao, Y.; Lan, L.; Lin, C.; Li, Y.; Xu, H.; Gong, M.; Chen, Y. The promotional effect of Ce on CuFe/beta monolith catalyst for selective catalytic reduction of $\mathrm{NO}_{x}$ by ammonia. Chem. Eng. J. 2016, 302, 697-706. [CrossRef]

22. Zhao, X.; Huang, L.; Li, H.; Hu, H.; Hu, X.; Shi, L.; Zhang, D. Promotional effects of zirconium doped CeVO $\mathrm{C}_{4}$ for the lowtemperature selective catalytic reduction of $\mathrm{NO}_{x}$ with $\mathrm{NH}_{3}$. Appl. Catal. B Environ. 2016, 183, 269-281. [CrossRef]

23. Liu, F.; Wang, Z.; Wang, D.; Chen, D.; Chen, F.; Li, X. Morphology and Crystal-Plane Effects of Fe/W-CeO 2 for Selective Catalytic Reduction of $\mathrm{NO}$ with $\mathrm{NH}_{3}$. Catalysts 2019, 9, 288. [CrossRef]

24. Yan, J.; Qiu, W.; Song, L.; Chen, Y.; Su, Y.; Bai, G.; Zhang, G.; He, H. Ligand-assisted mechanochemical synthesis of ceria-based catalysts for the selective catalytic reduction of $\mathrm{NO}_{\text {by NH}}$. Chem. Commun. 2017, 53, 1321-1324. [CrossRef] [PubMed]

25. Mullins, D.R. The surface chemistry of cerium oxide. Surf. Sci. Rep. 2015, 70, 42-85. [CrossRef]

26. Montini, T.; Melchionna, M.; Monai, M.; Fornasiero, P. Fundamentals and Catalytic Applications of $\mathrm{CeO}_{2}$-Based Materials. Chem. Rev. 2016, 116, 5987-6041. [CrossRef] [PubMed]

27. Ryou, Y.S.; Lee, J.; Lee, H.; Kim, C.H.; Kim, D.H. Effect of sulfur aging and regeneration on low temperature NO adsorption over hydrothermally treated $\mathrm{Pd} / \mathrm{CeO}_{2}$ and $\mathrm{Pd} / \mathrm{Ce}_{0.58} \mathrm{Zr}_{0.42} \mathrm{O}_{2}$ catalysts. Catal. Today 2017, 297, 53-59. [CrossRef]

28. Xu, J.; Yu, H.; Zhang, C.; Xie, J. Development of cerium-based catalysts for selective catalytic reduction of nitrogen oxides: Review. New J. Chem. 2019, 43, 3996-4007. [CrossRef]

29. Li, X.; Li, Y.; Deng, S.; Rong, T.A. A Ce-Sn-Ox catalyst for the selective catalytic reduction of $\mathrm{NO}_{x}$ with $\mathrm{NH}_{3}$. Catal. Commun. 2013, 40, 47-50. [CrossRef] 
30. Kwon, D.W.; Hong, S.C. Promotional effect of tungsten-doped $\mathrm{CeO}_{2} / \mathrm{TiO}_{2}$ for selective catalytic reduction of $\mathrm{NO}_{\mathrm{x}}$ with ammonia. Appl. Surf. Sci. 2015, 356, 181-190. [CrossRef]

31. Calatayud, M.; Mguig, B.; Minot, C. Modeling catalytic reduction of $\mathrm{NO}$ by ammonia over $\mathrm{V}_{2} \mathrm{O}_{5}$. Surf. Sci. Rep. 2004, 55, 169-236. [CrossRef]

32. Devaiah, D.; Thirupathi, B.; Padmanabha, R.E.; Reddy, B.M.; Smirniotis, P.G. Direct Decomposition of $\mathrm{NO}_{x}$ over TiO 2 Supported Transition Metal Oxides at Low Temperatures. Ind. Eng. Chem. Res. 2018, 57, 16615-16621.

33. Gao, X.; Jiang, Y.; Zhong, Y.; Luo, Z.; Cen, K. The activity and characterization of $\mathrm{CeO}_{2}-\mathrm{TiO}_{2}$ catalysts prepared by the sol-gel method for selective catalytic reduction of $\mathrm{NO}$ with $\mathrm{NH}_{3}$. J. Hazard. Mater. 2010, 174, 734-739. [CrossRef] [PubMed]

34. Gao, X.; Jiang, Y.; Fu, Y.; Zhong, Y.; Luo, Z.; Cen, K. Preparation and characterization of $\mathrm{CeO}_{2} / \mathrm{TiO}_{2}$ catalysts for selective catalytic reduction of $\mathrm{NO}$ with $\mathrm{NH}_{3}$. Catal. Commun. 2010, 11, 465-469. [CrossRef]

35. Duan, Z.; Liu, J.; Shi, J.; Zhao, Z.; Wei, Y.; Zhang, X.; Jiang, G.; Duan, A. The selective catalytic reduction of $\mathrm{NO}_{\text {over }} \mathrm{Ce}_{0.3} \mathrm{TiO}_{\mathrm{x}}$ supported metal oxide catalysts. J. Environ. Sci. 2018, 65, 1-7. [CrossRef]

36. Huang, X.; Li, S.; Qiu, W.; Chen, Y.; Cheng, J.; Sun, Y.; Bai, G.; Song, L.; Zhang, G.; He, H. Effect of Organic Assistant on the Performance of Ceria-Based Catalysts for the Selective Catalytic Reduction of NO with Ammonia. Catalysts 2019, 9, 357. [CrossRef]

37. Jin, Q.; Shen, Y.; Ma, L.; Pan, Y.; Zhu, S.; Zhang, J.; Zhou, W.; Wei, X.; Li, X. Novel $\mathrm{TiO}_{2}$ catalyst carriers with high thermostability

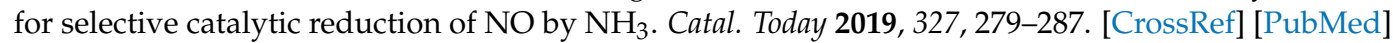

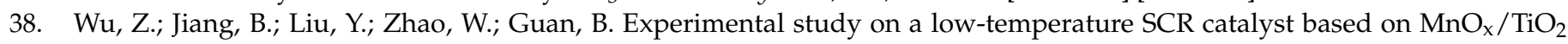
prepared by sol-gel method. J. Hazard. Mater. 2007, 145, 488-494. [CrossRef]

39. Fei, Z.; Yang, Y.; Wang, M.; Tao, Z.; Liu, Q.; Chen, X.; Cui, M.; Zhang, Z.; Tang, J.; Qiao, X. Precisely fabricating Ce-O-Ti structure to enhance performance of $\mathrm{Ce}-\mathrm{Ti}$ based catalysts for selective catalytic reduction of $\mathrm{NO}$ with $\mathrm{NH}_{3}$. Chem. Eng. J. 2018, 353, 930-939. [CrossRef]

40. Zhang, L.; Li, L.; Cao, Y.; Yao, X.; Ge, C.; Gao, F.; Deng, Y.; Tang, C.; Dong, L. Getting insight into the influence of $\mathrm{SO}_{2}$ on $\mathrm{TiO}_{2} / \mathrm{CeO}_{2}$ for the selective catalytic reduction of $\mathrm{NO}$ by NH $\mathrm{NH}_{3}$. Appl. Catal. B Environ. 2015, 165, 589-598. [CrossRef]

41. Yao, X.; Zhao, R.; Chen, L.; Du, J.; Tao, C.; Yang, F.; Dong, L. Selective catalytic reduction of $\mathrm{NO}_{x}$ by $\mathrm{NH}_{3}$ over $\mathrm{CeO}_{2}$ supported on $\mathrm{TiO}_{2}$ : Comparison of anatase, brookite, and rutile. Appl. Catal. B Environ. 2019, 208, 82-93. [CrossRef]

42. Xiao, X.; Xiong, S.; Shi, Y.; Shan, W.; Yang, S. Effect of $\mathrm{H}_{2} \mathrm{O}$ and $\mathrm{SO}_{2}$ on the Selective Catalytic Reduction of $\mathrm{NO}_{\text {with }} \mathrm{NH}_{3}$ over $\mathrm{Ce} / \mathrm{TiO}_{2}$ Catalyst: Mechanism and Kinetic Study. J. Phys. Chem. C 2016, 120, 1066-1076. [CrossRef]

43. Ye, B.; Lee, M.; Jeong, B.; Kim, J.; Lee, D.H.; Baik, J.M.; Kim, H.-D. Partially reduced graphene oxide as a support of Mn-Ce/TiO 2 catalyst for selective catalytic reduction of $\mathrm{NO}_{x}$ with $\mathrm{NH}_{3}$. Catal. Today 2019, 328, 300-306. [CrossRef]

44. Li, Y.; Li, Y.; Wan, Y.; Zhan, S.; Guan, Q.; Tian, Y. Structure-performance relationships of $\mathrm{MnO}_{2}$ nanocatalyst for the lowtemperature SCR removal of $\mathrm{NO}_{\mathrm{x}}$ under ammonia. RSC Adv. 2016, 6, 54926-54937. [CrossRef]

45. Li, J.; Chang, H.; Ma, L.; Hao, J.; Yang, R. Low-temperature selective catalytic reduction of $\mathrm{NO}_{x}$ with $\mathrm{NH}_{3}$ over metal oxide and zeolite catalysts: A review. Catal. Today 2011, 175, 147-156. [CrossRef]

46. Wang, X.; Li, X.; Zhao, Q.; Sun, W.; Tade, M.; Liu, S. Improved activity of W-modified $\mathrm{MnO}_{\mathrm{x}}-\mathrm{TiO}_{2}$ catalysts for the selective catalytic reduction of $\mathrm{NO}$ with $\mathrm{NH}_{3}$. Chem. Eng. J. 2016, 288, 216-222. [CrossRef]

47. Luo, S.; Zhou, W.; Xie, A.; Wu, F.; Yao, C.; Li, X.; Zuo, S.; Liu, T. Effect of $\mathrm{MnO}_{2}$ polymorphs structure on the selective catalytic reduction of $\mathrm{NO}_{x}$ with $\mathrm{NH}_{3}$ over $\mathrm{TiO}_{2}$-Palygorskite. Chem. Eng. J. 2016, 286, 291-299. [CrossRef]

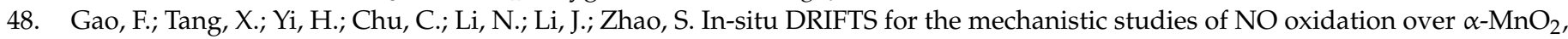
$\beta-\mathrm{MnO}_{2}$ and $\gamma-\mathrm{MnO}_{2}$ catalysts. Chem. Eng. J. 2017, 322, 525-537. [CrossRef]

49. Kapteijn, F.; Singoredjo, L.; Andreini, A.; Moulijn, J.A. Activity and selectivity of pure manganese oxides in the selective catalytic reduction of nitric oxide with ammonia. Appl. Catal. B Environ. 1994, 3, 173-189. [CrossRef]

50. Xu, H.; Yan, N.; Qu, Z.; Liu, W.; Mei, J.; Huang, W.; Zhao, S. Gaseous Heterogeneous Catalytic Reactions over Mn-Based Oxides for Environmental Applications: A Critical Review. Environ. Sci. Technol. 2017, 51, 8879-8892. [CrossRef] [PubMed]

51. Gao, C.; Shi, J.; Fan, Z.; Cao, G.; Niu, C. Sulfur and Water Resistance of Mn-Based Catalysts for Low-Temperature Selective Catalytic Reduction of $\mathrm{NO}_{\mathrm{x}}$ : A Review. Catalysts 2018, 8, 11. [CrossRef]

52. Kim, S.H.; Park, B.C.; Jeon, Y.S.; Kim, Y.K. $\mathrm{MnO}_{2}$ Nanowire- $\mathrm{CeO}_{2}$ Nanoparticle Composite Catalysts for the Selective Catalytic Reduction of $\mathrm{NO}_{x}$ with $\mathrm{NH}_{3}$. ACS Appl. Mater. Interfaces 2018, 10, 32112-32119. [CrossRef]

53. Liu, Y.; Gu, T.; Weng, X.; Wang, Y.; Wu, Z.; Wang, H. DRIFT Studies on the Selectivity Promotion Mechanism of Ca-Modified $\mathrm{Ce}-\mathrm{Mn} / \mathrm{TiO}_{2}$ Catalysts for Low-Temperature NO Reduction with $\mathrm{NH}_{3}$. J. Phys. Chem. A 2012, 116, 16582-16592. [CrossRef]

54. Qi, G.; Yang, R.; Chang, R. $\mathrm{MnO}_{\mathrm{x}}-\mathrm{CeO}_{2}$ mixed oxides prepared by co-precipitation for selective catalytic reduction of $\mathrm{NO}$ with $\mathrm{NH}_{3}$ at low temperatures. Appl. Catal. B Environ. 2004, 51, 93-106. [CrossRef]

55. Qi, G.; Yang, R. Characterization and FTIR studies of $\mathrm{MnO}_{\mathbf{x}}-\mathrm{CeO}_{2}$ catalyst for low-temperature selective catalytic reduction of $\mathrm{NO}$ with $\mathrm{NH}_{3}$. Phys. Chem. B 2004, 108, 15738-15747. [CrossRef]

56. Shen, B.; Wang, F.; Liu, T. Homogeneous $\mathrm{MnO}_{x}-\mathrm{CeO}_{2}$ pellets prepared by a one-step hydrolysis process for low-temperature $\mathrm{NH}_{3}$-SCR. Front. Environ. Sci. Eng. 2004, 253, 152-157.

57. Yao, X.; Ma, K.; Zou, W.; He, S.; An, J.; Yang, F.; Dong, L. Influence of preparation methods on the physicochemical properties and catalytic performance of $\mathrm{MnO}_{x}-\mathrm{CeO}_{2}$ catalysts for $\mathrm{NH}_{3}-\mathrm{SCR}$ at low temperature. Chin. J. Catal. 2017, 38, 146-159. [CrossRef] 
58. Andreoli, S.; Deorsola, F.A.; Pirone, R. $\mathrm{MnO}_{\mathrm{x}}-\mathrm{CeO}_{2}$ catalysts synthesized by solution combustion synthesis for the lowtemperature $\mathrm{NH}_{3}$-SCR. Catal. Today 2015, 235, 199-206. [CrossRef]

59. Liu, Z.; Yi, Y.; Zhang, S.; Zhu, T.; Zhu, J.; Wang, J. Selective catalytic reduction of $\mathrm{NO}_{\mathrm{x}}$ with $\mathrm{NH}_{3}$ over Mn-Ce mixed oxide catalyst at low temperatures. Catal. Today 2013, 216, 76-81. [CrossRef]

60. Xu, L.; Li, X.S.; Crocker, M.; Zhang, Z.S.; Zhu, A.-M.; Shi, C. A study of the mechanism of low-temperature SCR of NO with $\mathrm{NH}_{3}$ on $\mathrm{MnO}_{\mathrm{x}} / \mathrm{CeO}_{2}$. J. Mol. Catal. A Chem. 2013, 378, 82-90. [CrossRef]

61. Wang, D.; Peng, Y.; Yang, Q.; Hu, F.; Li, J.; Crittenden, J. $\mathrm{NH}_{3}-\mathrm{SCR}$ performance of $\mathrm{WO}_{3}$ blanketed CeO 2 with different morphology: Balance of surface reducibility and acidity. Catal. Today 2019, 332, 42-48. [CrossRef]

62. Liu, C.; Chen, L.; Chang, H.; Ma, L.; Peng, Y.; Arandiyan, H.; Li, J. Characterization of $\mathrm{CeO}_{2}-\mathrm{WO}_{3}$ catalysts prepared by different methods for selective catalytic reduction of $\mathrm{NO}_{x}$ with $\mathrm{NH}_{3}$. Catal. Commun. 2013, 40, 145-148. [CrossRef]

63. Liu, Z.; Feng, X.; Zhou, Z.; Feng, Y.; Li, J. Ce-Sn binary oxide catalyst for the selective catalytic reduction of $\mathrm{NO}_{\mathbf{x}}$ by $\mathrm{NH}_{3}$. Appl. Surf. Sci. 2018, 428, 526-533. [CrossRef]

64. Peng, Y.; Qu, R.; Zhang, X.; Li, J. The relationship between structure and activity of $\mathrm{MoO}_{3}-\mathrm{CeO}_{2}$ catalysts for $\mathrm{NO}$ removal: Influences of acidity and reducibility. Chem. Commun. 2013, 49, 6215-6217. [CrossRef]

65. Gao, X.; Du, X.; Cui, L.; Fu, Y.; Luo, Z.; Cen, K. A Ce-Cu-Ti oxide catalyst for the selective catalytic reduction of $\mathrm{NO}_{\text {with }} \mathrm{NH}_{3}$. Catal. Commun. 2010, 12, 255-258. [CrossRef]

66. Zhang, L.; Qu, H.; Du, T.; Ma, W.; Zhong, Q. $\mathrm{H}_{2} \mathrm{O}$ and $\mathrm{SO}_{2}$ tolerance, activity and reaction mechanism of sulfated Ni-Ce-La composite oxide nanocrystals in $\mathrm{NH}_{3}$-SCR. Chem. Eng. J. 2016, 296, 122-131. [CrossRef]

67. Atribak, I.; Bueno-López, A.; García-García, A. Thermally stable ceria-zirconia catalysts for soot oxidation by $\mathrm{O}_{2}$. Catal. Commun. 2008, 9, 250-255. [CrossRef]

68. Shang, D.; Zhong, Q.; Cai, W. High performance of NO oxidation over Ce-Co-Ti catalyst: The interaction between Ce and Co. Appl. Surf. Sci. 2015, 325, 211-216. [CrossRef]

69. Gonçalves, A.A.S.; Ciesielczyk, F.; Samojeden, B.; Jaroniec, M. Toward Development of Single-Atom Ceramic Catalysts for Selective Catalytic Reduction of $\mathrm{NO}$ with $\mathrm{NH}_{3}$. J. Hazard. Mater. 2021, 401, 123413. [CrossRef] [PubMed]

70. Lu, Y.; Zhang, Z.; Lin, F.; Wang, H.; Wang, Y. Single-atom Automobile Exhaust Catalysts. ChemNanoMat 2020, 6, 1659-1682. [CrossRef]

71. Zhang, Q.; Qiu, C.; Xu, H.; Lin, T.; Lin, Z.; Guo, M.; Chen, Y. Low-temperature selective catalytic reduction of $\mathrm{NO}_{\text {with }} \mathrm{NH}_{3}$ over monolith catalyst of $\mathrm{MnO}_{x} / \mathrm{CeO}_{2}-\mathrm{ZrO}_{2}-\mathrm{Al}_{2} \mathrm{O}_{3}$. Catal. Today 2011, 175, 171-176. [CrossRef]

72. Ko, J.H.; Park, S.H.; Jeon, J.-K.; Kim, S.-S.; Kim, S.C.; Kim, J.M.; Chang, D.; Park, Y.-K. Low temperature selective catalytic reduction of $\mathrm{NO}$ with $\mathrm{NH}_{3}$ over $\mathrm{Mn}$ supported on $\mathrm{Ce}_{0.65} \mathrm{Zr}_{0.35} \mathrm{O}_{2}$ prepared by supercritical method: Effect of Mn precursors on NO reduction. Catal. Today 2012, 185, 290-295. [CrossRef]

73. Andreoli, S.; Deorsola, F.A.; Galletti, C.; Pirone, R. Nanostructured $\mathrm{MnO}_{\mathrm{x}}$ catalysts for low-temperature $\mathrm{NO}_{\mathrm{x}} \mathrm{SCR}$. Chem. Eng. J. 2015, 278, 174-182. [CrossRef]

74. Fan, X.; Qiu, F.; Yang, H.; Tian, W.; Hou, T.; Zhang, X. Selective catalytic reduction of $\mathrm{NO}_{\mathrm{x}}$ with ammonia over $\mathrm{Mn}_{-}-\mathrm{CeO}_{\mathrm{x}} / \mathrm{TiO}{ }_{2}$ carbon nanotube composites. Catal. Commun. 2011, 12, 1298-1301. [CrossRef]

75. Liu, Z.; Zhu, J.; Li, J.; Ma, L.; Woo, S.I. Novel Mn-Ce-Ti Mixed-Oxide Catalyst for the Selective Catalytic Reduction of $\mathrm{NO}_{\mathrm{x}}$ with $\mathrm{NH}_{3}$. ACS Appl. 2014, 6, 14500-14508. [CrossRef]

76. Shen, B.; Yao, Y.; Ma, H.; Liu, T. Ceria Modified $\mathrm{MnO}_{\mathrm{x}} / \mathrm{TiO}_{2}$-Pillared Clays Catalysts for the Selective Catalytic Reduction of NO with $\mathrm{NH}_{3}$ at Low Temperature. Chin. J. Catal. 2011, 32, 1803-1811. [CrossRef]

77. Xu, Q.; Su, R.; Cao, L.; Li, Y.; Yang, C.; Luo, Y.; Street, J.; Jiao, P.; Cai, L. Facile preparation of high-performance Fe-doped $\mathrm{Ce}-\mathrm{Mn} / \mathrm{TiO}_{2}$ catalysts for the low-temperature selective catalytic reduction of $\mathrm{NO}_{\mathrm{x}}$ with $\mathrm{NH}_{3}$. RSC Adv. 2017, 7, 48785-48792 [CrossRef]

78. Wu, Z.; Jin, R.; Wang, H.; Liu, Y. Effect of Ceria Doping on $\mathrm{SO}_{2}$ Resistance of $\mathrm{Mn} / \mathrm{TiO}_{2}$ for Selective Catalytic Reduction of $\mathrm{NO}$ with $\mathrm{NH}_{3}$ at Low Temperature. Catal. Commun. 2009, 10, 935-939. [CrossRef]

79. Sheng, Z.; Hu, Y.; Xue, J.; Wang, X.; Liao, W. $\mathrm{SO}_{2}$ poisoning and regeneration of $\mathrm{Mn}-\mathrm{Ce} / \mathrm{TiO}_{2}$ catalyst for low temperature $\mathrm{NO}_{\mathrm{x}}$ reduction with $\mathrm{NH}_{3}$. J. Rare Earths 2012, 30, 676-682. [CrossRef]

80. Peng, Y.; Li, J.; Si, W.; Li, X.; Shi, W.; Luo, J.; Fu, J.; Crittenden, J.; Hao, J. Ceria promotion on the potassium resistance of $\mathrm{MnO}_{\mathrm{x}} / \mathrm{TiO}_{2}$ SCR catalysts: An experimental and DFT study. Chem. Eng. J. 2015, 269, 44-50. [CrossRef]

81. Casapu, M.; Krocher, O.; Elsener, M. Screening of doped $\mathrm{MnO}_{\mathbf{x}}-\mathrm{CeO}_{\mathrm{x}}$ catalysts for low-temperature NO-SCR. Appl. Catal. B Environ. 2009, 88, 413-419. [CrossRef]

82. Chen, L.; Li, J.; Ge, M.; Zhu, R. Enhanced activity of tungsten modified $\mathrm{CeO}_{2} / \mathrm{TiO}_{2}$ for selective catalytic reduction of $\mathrm{NO}_{\mathrm{x}}$ with ammonia. Catal. Today 2010, 153, 77-83. [CrossRef]

83. Yang, G.; Shan, W.; Xiong, S.; Liao, Y.; Yang, S.; Liu, F. Effect of $\mathrm{CeO}_{2}$ for a high-efficiency $\mathrm{CeO}_{2} / \mathrm{WO}_{3}-\mathrm{TiO}_{2}$ catalyst on $\mathrm{N}_{2} \mathrm{O}$ formation in $\mathrm{NH}_{3}$-SCR: A kinetic study. Catal. Sci. Technol. 2016, 6, 3149-3155.

84. Li, Y.; Cheng, H.; Li, D.; Qin, Y.; Xie, Y.; Wang, $\mathrm{S}$. $\mathrm{WO}_{3} / \mathrm{CeO}_{2}-\mathrm{ZrO}_{2}$, a promising catalyst for selective catalytic reduction (SCR) of $\mathrm{NO}_{x}$ with $\mathrm{NH}_{3}$ in diesel exhaust. Chem. Commun. 2008, 39, 1470-1472. [CrossRef]

85. Chen, L.; Weng, D.; Wang, J.; Weng, D.; Cao, L. Low-temperature activity and mechanism of $\mathrm{WO}_{3}-\mathrm{modified}^{\mathrm{CeO}} \mathrm{O}_{2}-\mathrm{TiO}_{2}$ catalyst under $\mathrm{NH}_{3}-\mathrm{NO} / \mathrm{NO}_{2}$ SCR conditions. Chin. J. Catal. 2018, 39, 1804-1813. [CrossRef] 
86. Guo, J.; Zhang, G.; Tang, Z.; Zhang, J. Controlled Synthesis of Mesoporous $\mathrm{CeO}_{2}-\mathrm{WO}_{3} / \mathrm{TiO}_{2}$ Microspheres Catalysts for the Selective Catalytic Reduction of $\mathrm{NO}_{x}$ with $\mathrm{NH}_{3}$. Catal. Surv. Asia 2019, 23, 311-321. [CrossRef]

87. Zha, K.; Cai, S.; Hu, H.; Li, H.; Yan, T.; Shi, L.; Zhang, D. In Situ DRIFTs Investigation of Promotional Effects of Tungsten on $\mathrm{MnO}_{\mathrm{x}}-\mathrm{CeO}_{2} /$ meso-TiO 2 Catalysts for $\mathrm{NO}_{\mathbf{x}}$ Reduction. J. Phys. Chem. C 2017, 121, 25243-25254. [CrossRef]

88. Katarzyna, A.M.M.; Ye, L.; Kazimierz, K.; Thomas, G.; Maarten, N.; Oliver, K.; Davide, F. Flame-Made $\mathrm{WO}_{3} / \mathrm{CeO}_{\mathbf{x}}-\mathrm{TiO}_{2} \mathrm{Catalysts}$ for Selective Catalytic Reduction of $\mathrm{NO}_{x}$ by $\mathrm{NH}_{3}$. ACS Catal. 2015, 5, 5657-5672. [CrossRef]

89. Fan, R.; Li, Z.; Wang, Y.; Zhang, C.; Wang, Y.; Ding, Z.; Guo, X.; Wang, R. Effects of $\mathrm{WO}_{3}$ and $\mathrm{SiO}_{2}$ doping on $\mathrm{CeO}_{2}-\mathrm{TiO}_{2}$ catalysts for selective catalytic reduction of NO with ammonia. RSC Adv. 2020, 10, 5845-5852. [CrossRef]

90. Salazar, M.; Becker, R.; Grünert, W.A. A close-up to the promoting effect of tungsten in $\mathrm{Ce} / \mathrm{TiO}_{2}$ catalysts for the selective catalytic reduction of $\mathrm{NO}$ with $\mathrm{NH}_{3}$. Mol. Catal. 2018, 451, 66-75. [CrossRef]

91. Shan, W.; Liu, F.; He, H.; Shi, X.; Zhang, C. A superior Ce-W-Ti mixed oxide catalyst for the selective catalytic reduction of $\mathrm{NO}_{\mathrm{x}}$ with $\mathrm{NH}_{3}$. Appl. Catal. B Environ. 2012, 115-116, 100-106. [CrossRef]

92. Bian, X.; Hu, L.; Peng, P.; Liu, S. Preparation and performance of $\mathrm{xCeO}_{2}-\mathrm{yWO}_{3}-\mathrm{TiO}_{2}$ catalyst. J. Northeast. Univ. 2019, 40, 1716-1720.

93. Jiang, Y.; Zhang, X.; Lu, M.; Bao, C.; Liang, G.; Lai, C.; Shi, W.; Ma, S. Activity and characterization of Ce-Mo-Ti mixed oxide catalysts prepared by a homogeneous precipitation method for selective catalytic reduction of $\mathrm{NO}$ with $\mathrm{NH}_{3}$. J. Taiwan Inst. Chem. Eng. 2018, 86, 133-140. [CrossRef]

94. Liu, Z.; Zhang, S.; Li, J.; Ma, L. Promoting effect of $\mathrm{MoO}_{3}$ on the $\mathrm{NO}_{\mathrm{x}}$ reduction by $\mathrm{NH}_{3}$ over $\mathrm{CeO}_{2} / \mathrm{TiO}_{2}$ catalyst studied with in situ DRIFTS. Appl. Catal. B Environ. 2014, 144, 90-95. [CrossRef]

95. Xu, W.; Gao, L.; Yang, Y.; Zhu, T.; Qi, G. Effects of $\mathrm{MoO}_{3}$ and $\mathrm{CeO}_{2}$ doping on the decomposition and reactivity of $\mathrm{NH}_{4} \mathrm{HSO}_{4}$ on $\mathrm{V}_{2} \mathrm{O}_{5} / \mathrm{TiO}_{2}$ catalysts. Environ. Sci. Pollut. Res. 2020, 27, 30243-30253. [CrossRef]

96. Li, L.; Li, P.; Tan, W.; Ma, K.; Zou, W.; Tang, C.; Dong, L. Enhanced low-temperature $\mathrm{NH}_{3}-\mathrm{SCR}$ performance of CeTiO $\mathrm{x}_{\mathrm{x}}$ catalyst via surface Mo modification. Chin. J. Catal. 2020, 41, 364-373. [CrossRef]

97. Liu, Z.; Zhu, J.; Zhang, S.; Ma, L.; Woo, S.I. Selective catalytic reduction of $\mathrm{NO}_{x}$ by $\mathrm{NH}_{3}$ over $\mathrm{MoO}_{3}$-promoted $\mathrm{CeO}_{2} / \mathrm{TiO}_{2}$ catalyst. Catal. Commun. 2014, 46, 90-93. [CrossRef]

98. Jiang, Y.; Wang, X.; Xing, Z.; Bao, C.; Liang, G. Preparation and Characterization of $\mathrm{CeO}_{2}-\mathrm{MoO}_{3} / \mathrm{TiO} 2$ Catalysts for Selective Catalytic Reduction of $\mathrm{NO}$ with $\mathrm{NH}_{3}$. Aerosol Air Qual. Res. 2017, 17, 2726-2734. [CrossRef]

99. Jiang, Y.; Bao, C.; Liu, Q.; Liang, G.; Lu, M.; Ma, S. A novel $\mathrm{CeO}_{2}-\mathrm{MoO}_{3}-\mathrm{WO}_{3} / \mathrm{TiO}_{2}$ catalyst for selective catalytic reduction of $\mathrm{NO}$ with $\mathrm{NH}_{3}$. Catal. Commun. 2018, 103, 96-100. [CrossRef]

100. Zhang, G.; Huang, X.; Yang, X.; Tang, Z. Comprehensive study of the promotional mechanism of $\mathrm{F}$ on Ce-Mo/ TiO 2 catalysts for wide temperature $\mathrm{NH}_{3}$-SCR performance: The activation of surface Ti-F bonds. Catal. Sci. Technol. 2019, 9, 2231-2244. [CrossRef]

101. Li, X.; Li, X.; Li, J.; Hao, J. Identification of the arsenic resistance on $\mathrm{MoO}_{3}$ doped $\mathrm{CeO}_{2} / \mathrm{TiO}_{2}$ catalyst for selective catalytic reduction of $\mathrm{NO}_{\mathrm{x}}$ with ammonia. J. Hazard. Mater. 2016, 318, 615-622. [CrossRef]

102. Zhang, G.; Han, W.; Zhao, H.; Zong, L.; Tang, Z. Solvothermal synthesis of well-designed ceria-tin-titanium catalysts with enhanced catalytic performance for wide temperature $\mathrm{NH}_{3}-\mathrm{SCR}$ reaction. Appl. Catal. B Environ. 2018, 226, 117-126. [CrossRef]

103. Lian, Z.; Liu, F; He, H. Enhanced Activity of Ti-Modified $\mathrm{V}_{2} \mathrm{O}_{5} / \mathrm{CeO}_{2}$ Catalyst for the Selective Catalytic Reduction of $\mathrm{NO}_{x}$ with $\mathrm{NH}_{3}$. Ind. Eng. Chem. Res. 2014, 53, 19506-19511. [CrossRef]

104. Li, L.; Zhang, L.; Ma, K.; Zou, W.; Cao, Y.; Xiong, Y.; Tang, C.; Dong, L. Ultra-low loading of copper modified $\mathrm{TiO}_{2} / \mathrm{CeO}_{2}$ catalysts for low-temperature selective catalytic reduction of $\mathrm{NO}$ by $\mathrm{NH}_{3}$. Appl. Catal. B Environ. 2017, 207, 366-375. [CrossRef]

105. Mosrati, J.; Atia, H.; Eckelt, R.; Lund, H.; Agostini, G.; Bentrup, U.; Rockstroh, N.; Keller, S.; Armbruster, U.; Mhamdi, M. $\mathrm{Nb}$-Modified $\mathrm{Ce} / \mathrm{Ti}$ Oxide Catalyst for the Selective Catalytic Reduction of $\mathrm{NO}$ with $\mathrm{NH}_{3}$ at Low Temperature. Catalysts 2018, 8, 175. [CrossRef]

106. Zhao, W.; Li, Z.; Wang, Y.; Fan, R.; Zhang, C.; Wang, Y.; Guo, X.; Wang, R.; Zhang, S. Ce and Zr Modified $\mathrm{WO}_{3}-\mathrm{TiO}_{2}$ Catalysts for Selective Catalytic Reduction of $\mathrm{NO}_{x}$ by $\mathrm{NH}_{3}$. Catalysts 2018, 8, 375. [CrossRef]

107. Liu, J.; Li, X.; Zhao, Q.; Ke, J.; Xiao, H.; Lv, X.; Liu, S.; Tadé, M.; Wang, S. Mechanistic investigation of the enhanced NH 3 -SCR on cobalt-decorated Ce-Ti mixed oxide: In situ FTIR analysis for structure-activity correlation. Appl. Catal. B Environ. 2017, 200, 297-308. [CrossRef]

108. Li, W.; Zhang, C.; Li, X.; Tan, P.; Zhou, A.; Fang, Q.; Chen, G. Ho-modified Mn-Ce/ $\mathrm{TiO}_{2}$ for low-temperature SCR of NO with $\mathrm{NH}_{3}$ : Evaluation and characterization. Chin. J. Catal. 2018, 39, 1653-1663. [CrossRef]

109. Hirofumi, O.; Takeshi, T.; Osamu, O.; Sabatino, L.M.F.; Bellussi, G. A study on the roles of cobalt species in $\mathrm{NO}_{\mathbf{x}}$ reduction by propane on CO-Beta. Catal. Today 1998, 42, 45-50. [CrossRef]

110. Rahkamaa-Tolonen, K.; Maunula, T.; Lomma, M.; Huuhtanen, M.; Keiski, R.L. The effect of $\mathrm{NO}_{2}$ on the activity of fresh and aged zeolite catalysts in the $\mathrm{NH}_{3}$-SCR reaction. Catal. Today 2005, 100, 217-222. [CrossRef]

111. Rivallan, M.; Berlier, G.; Ricchiardi, G.; Zecchina, A.; Nechita, M.T.; Olsbye, U. Characterisation and catalytic activity in de-NO reactions of Fe-ZSM-5 zeolites prepared via ferric oxalate precursor. Appl. Catal. B Environ. 2008, 84, 204-213. [CrossRef]

112. Cimino, S.; Lisi, L.; Tortorelli, M. Low temperature SCR on supported $\mathrm{MnO}_{\mathrm{x}}$ catalysts for marine exhaust gas cleaning: Effect of $\mathrm{KCl}$ poisoning. Chem. Eng. J. 2016, 283, 223-230. [CrossRef]

113. Xia, Y.; Zhan, W.; Guo, Y.; Guo, Y.L.; Lu, G. Fe-Beta zeolite for selective catalytic reduction of $\mathrm{NO}_{\mathrm{x}}$ with $\mathrm{NH}_{3}$ : Influence of Fe content. Chin. J. Catal. 2016, 37, 2069-2078. [CrossRef] 
114. Qi, G.; Yang, R. Ultra-active Fe/ZSM-5 catalyst for selective catalytic reduction of nitric oxide with ammonia. Appl. Catal. B Environ. 2005, 60, 13-22. [CrossRef]

115. Krishna, K.; Seijger, G.B.F.; van der Bleek, G.M.; Calis, H.P.A. Very active $\mathrm{CeO}_{2}$-zeolite catalysts for $\mathrm{NO}_{\mathrm{x}}$ reduction with $\mathrm{NH}_{3}$. Chem. Commun. 2002, 18, 2030-2031. [CrossRef]

116. Liu, X.; Wu, X.; Weng, D.; Shi, L. Modification of Cu/ZSM-5 catalyst with $\mathrm{CeO}_{2}$ for selective catalytic reduction of $\mathrm{NO}_{\mathrm{x}}$ with ammonia. J. Rare Earths 2016, 34, 1004-1009. [CrossRef]

117. Dou, B.; Lv, G.; Wang, C.; Hao, Q.; Hui, K. Cerium doped copper/ZSM-5 catalysts used for the selective catalytic reduction of nitrogen oxide with ammonia. Chem. Eng. J. 2015, 270, 549-556. [CrossRef]

118. Chen, L.; Wang, X.; Cong, Q.; Ma, H.; Li, S.; Li, W. Design of a hierarchical Fe-ZSM-5@ CeO 2 catalyst and the enhanced performances for the selective catalytic reduction of $\mathrm{NO}$ with $\mathrm{NH}_{3}$. Chem. Eng. J. 2019, 369, 957-967. [CrossRef]

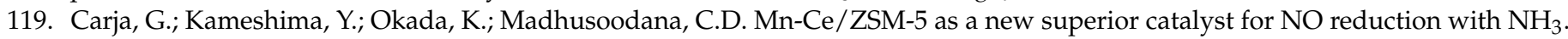
Appl. Catal. B Environ. 2007, 73, 60-64. [CrossRef]

120. Liu, Y.; Song, C.; Lv, G.; Fan, C.; Li, X. Promotional Effect of Cerium and/or Zirconium Doping on Cu/ZSM-5 Catalysts for Selective Catalytic Reduction of $\mathrm{NO}$ by $\mathrm{NH}_{3}$. Catalysts 2018, 8, 306. [CrossRef]

121. Liu, J.; Du, Y.; Liu, J.; Zhao, Z.; Cheng, K.; Chen, Y.; Wei, Y.; Song, W.; Zhang, X. Design of MoFe/Beta@CeO 2 catalysts with a coreshell structure and their catalytic performances for the selective catalytic reduction of $\mathrm{NO}$ with $\mathrm{NH}_{3}$. Appl. Catal. B Environ. 2017, 203, 704-714. [CrossRef]

122. Huang, Z.; Li, C.; Wang, Z.; Xu, S. Low temperature $\mathrm{NH}_{3}$-SCR denitration performance of different molecular sieves supported Mn-Ce catalysts. J. Fuel. Chem. Technol. 2016, 44, 1388-1394. 